\title{
The Scope and Limitations of Intramolecular Radical Cyclizations of Acylsilanes with Alkyl, Aryl, and Vinyl Radicals
}

\author{
Sheng-Yueh Chang, Weir-Torn J iaang, Chaur-Donp Cherng, Kuo-Hsiang Tang, \\ Chih-Hao Huang, and Yeun-Min Tsai*
}

Department of Chemistry, National Taiwan University, Taipei, Taiwan 106, Republic of China

Received J une $20,1997^{\otimes}$

\begin{abstract}
5-Exo cyclizations of primary and secondary radicals with acylsilanes successfully give cyclopentyl silyl ethers. The corresponding 6-exo cyclizations are sensitive to changes of the size of silyl groups. Secondary radicals undergo 6-exo cyclizations with acylsilanes more slowly. Reaction of aryl radical with acylsilane proceeds well for 5-exo cyclization but not for 6-exo cyclization. Vinyl radicals give best results in 5-exo cyclizations with acylsilanes but give low yields $(\sim 30 \%)$ in 6 -exo cyclizations. Intramolecular cyclizations of vinyl radicals with acylsilanes give enol silyl ethers regiospecifically.
\end{abstract}

\section{Introduction}

Radical addition to carbon-carbon multiple bonds is an important strategy in the construction of carbocycles or heterocycles. ${ }^{1}$ A carbon-carbon double bond is the most often used radical acceptor in this type of strategy. When a carbon-carbon double bond is used for cyclization, the cyclic structure obtained is al ways accompanied by an additional carbon appendage. This may sometimes be an unwanted feature. Although the carbonyl chemistry constitutes a major part of the organic chemistry, it was not until recently that the radical addition to carbonyls attracted the attention of synthetic organic chemists. ${ }^{2-4}$ When the carbonyl is used as the radical acceptor, a cyclic alcohol is obtained. This alcohol does

${ }^{\otimes}$ Abstract published in Advance ACS Abstracts, December 1, 1997. (1) (a) Fossey, J .; Lefort, D.; Sorba, J. Free Radicals in Organic Chemistry; Wiley: New York, 1995. (b) Giese, B.; Kopping, B.; Göbel, T.; Dickhaut, J .; Thoma, G.; Kulicke, K. J .; Trach, F. Org. React. 1996 48,303

(2) (a) Tsang, R.; Fraser-Reid, B. J . Am. Chem. Soc. 1986, 108, 2116, 8102. (b) Tsang, R.; Dickson, J r., J. K.; Pak, H.; Walton, R.; FraserReid, B. J . Am. Chem. Soc. 1987, 109, 3484. (c) Dickson, J . K., J r.; Tsang, R.; Llera, J . M.; Fraser-Reid, B. J . Org. Chem. 1989, 54, 5350. (d) Walton, R.; Fraser-Reid, B. J . Am. Chem. Soc. 1991, 113, 5791. (e) Paquette, L. A.; Ra, C. S.; Silvestri, T. W. Tetrahedron 1989, 45, 3099. (f) Knapp, S.; Gibson, F. S.; Choe, Y. H. Tetrahedron Lett. 1990, 38 5397. (g) Knapp, S.; Gibson, F. S. J . Org. Chem. 1992, 57, 4802. (h) Grissom, J. W.; Klingberg, D. J . Org. Chem. 1993, 58, 6559. (i) Grissom, J. W.; Klingberg, D.; Meyenburg, S.; Stallman, B. L. J . Org. Chem. 1994, 59, 7876. (j) Clive, D. L. J .; Postema, M. H. D. J. Chem. Soc., Chem. Commun. 1993, 429. (k) j ung, M. E.; Choe, S. W. T. Tetrahedron Lett. 1993, 34, 6247. (I) Hays, D. S.; Fu, G. C. J . Am. Chem. Soc. 1995 117, 7283 .

(3) For the use of radical addition to carbonyl in ring expansion reactions, see: (a) Beckwith, A. L. J .; O'Shea, D. M.; Gerba, S.; Westwood, S. W. J . Chem. Soc., Chem. Commun. 1987, 666. (b) Beckwith, A. L.J .; O'Shea, D. M.; Westwood, S. W. J . Am. Chem. Soc. 1988, 110, 2565. (c) Dowd, P.; Choi, S.-C. J . Am. Chem. Soc. 1987, 109, 3493, 6548. (d) Dowd, P.; Zhang, W. Chem. Rev. (Washington, D.C.) 1993, 93, 2091. (e) Zhang, W.; Dowd, P. Tetrahedron Lett. 1996, 37, 957. (f) Nishida, A.; Takahashi, H.; Takeda, H.; Takada, N.; Yonemitsu, O. J . Am. Chem. Soc. 1990, 112, 902. (g) Boger, D. L.; Mathvink, R. J J. Org. Chem. 1990, 55, 5442. (h) Baldwin, J. E.; Adlington, R. M.; Singh, R. Tetrahedron 1992, 48, 3385. (i) Crimmins, M. T.; Dudek, C. M.; Cheung, A. W.-H. Tetrahedron Lett. 1992, 33, 181. (j) Bowman, W. R.; Westlake, P. J . Tetrahedron 1992, 48, 4027. (k) Dygutsch, D. P.; Newmann, W. P.; Peterseim, M. Synlett 1994, 363. (I) Nemoto, H.; Shiraki, M.; Yamada, N.; Raku, N.; Fukumoto, K. Tetrahedron Lett. 1996, 37, 6355. (m) Nemoto, H.; Shiraki, M.; Yamada, N.; Raku, N.; Fukumoto, K. Tetrahedron 1996, 52, 13339.

(4) For acyl migration, see: (a) Giese, B.; Heinrich, N.; Horler, H.; Koch, W.; Schwarz, H. Chem. Ber. 1986, 119, 3528. (b) Wollowitz, S.; Halpern, J .J . Am. Chem. Soc. 1988, 110, 3112. (c) Renaud, P.; Vionnet, J .-P. J . Org. Chem. 1993, 58, 5895. (d) Leardini, R.; Lucarini, M.; Nanni, A.; Nanni, D.; Pedulli, G. F.; Tundo, A.; Zanardi, G. J . Org. Chem. 1993, 58, 2419. (e) Chen, S.-H.; Huang, S.; Gao, Q.; Golik, J.; Farina, V. J . Org. Chem. 1994, 59, 1475. (f) Kaliappan, K.; Rao, G. S. R. S. J . Chem. Soc., Chem. Commun. 1996, 2331.
Scheme 1

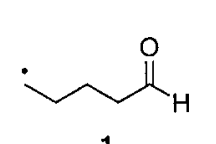

1<smiles>CCCCCC=O</smiles>

3 $k_{-1}$

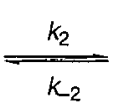

$k_{2}$<smiles>C1CCCCCC1</smiles>

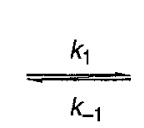

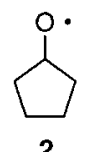

2<smiles>[C+]C1CCCCC1</smiles>

4 not have the extra carbon appendage on the ring as in the olefin system mentioned above. In addition, the resulting hydroxyl group can be transformed to other useful functional groups very easily. Therefore, the radical carbonyl cyclization reaction is a potentially useful process. ${ }^{2}$

As shown in Scheme 1,5 Beckwith's kinetic data reveal that the $k_{1}$ value for 5-exo ring closure of 4-formylbutyl radical (1) is $8.7 \times 10^{5} \mathrm{~s}^{-1}$ at $80{ }^{\circ} \mathrm{C}$. This value is comparable with the value of $1.4 \times 10^{6} \mathrm{~s}^{-1}\left(80^{\circ} \mathrm{C}\right)$ for 5 -exo ring closure of 5-hexenyl radical.5b,6,7 In the case of 5-formylpentyl radical (3), $\mathrm{k}_{2}$ is $1.0 \times 10^{6} \mathrm{~s}^{-1}\left(80^{\circ} \mathrm{C}\right)$, which is faster than that for 6-exo ring closure of 6-heptenyl radical $\left(4.3 \times 10^{4} \mathrm{~s}^{-1}\right.$ at $\left.80^{\circ} \mathrm{C}\right) .5 \mathrm{~b}, 6$ The problem of the two cyclization systems shown in Scheme 1 is that the ring openings of alkoxy radicals $2\left(\mathrm{k}_{-1}=\right.$ $4.7 \times 10^{8} \mathrm{~s}^{-1}$ at $\left.80^{\circ} \mathrm{C}\right)$ and $4\left(\mathrm{k}_{-2}=1.1 \times 10^{7} \mathrm{~s}^{-1}\right.$ at 80 ${ }^{\circ} \mathrm{C}$ ) are faster than the cyclizations. In fact, the most useful application of radical addition to carbonyl compounds relies on the controlled ring openings of the cyclized alkoxy radicals to prepare ring expansion products. $^{3}$

To drive these kind of neutral carbonyl addition reactions to the right-hand side, one methodology is to trap or convert the cyclized alkoxy radical irreversibly. A successful demonstration of this idea is the acylsilane system developed by us. ${ }^{8}$ Using radical $\mathbf{5}$ derived from 5-bromoacylsilane for illustration (Scheme 2), the 5-exo ring closure product $\mathbf{6}$ undergoes a facile radical-Brook rearrangement ${ }^{9}$ to give $\alpha$-silyloxy radical 7 . Due to the strong bonding energy of $\mathrm{O}-\mathrm{Si}^{10}$ the silyl migration is

(5) (a) Beckwith, A. L. J .; Hay, B. P. J . Am. Chem. Soc. 1989, 111, 230, 2674. (b) Beckwith, A. L. J .; Raner, K. D. J . Org. Chem. 1992, 57 4954.

(6) Beckwith, A. L. J . Tetrahedron 1981, 37, 3073

(7) Lusztyk, J .; Maillard, B.; Deycard, S.; Lindsay, D. A.; Ingold, K. U. J. Org. Chem. 1987, 52, 3509. 


\section{Scheme 2}

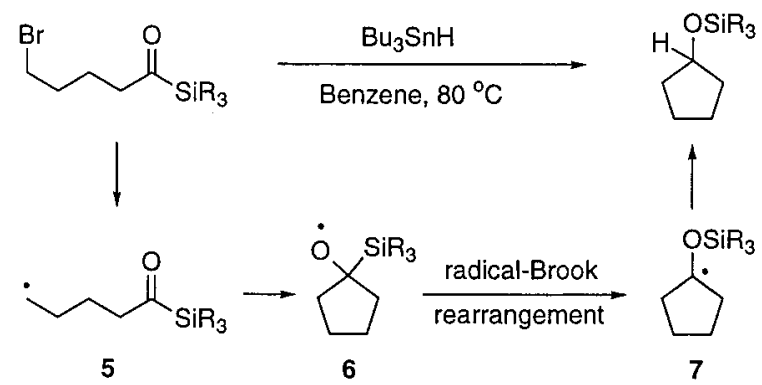

Scheme 3

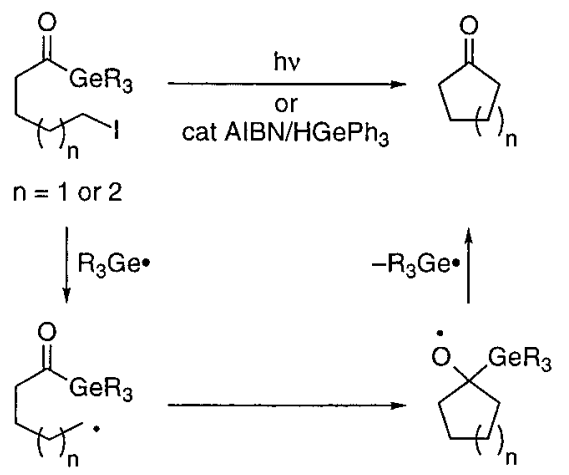

most likely irreversible. Therefore, the cyclization step is essentially driven toward the right-hand side by this design. The cyclization of 4-silylcarbonylbutyl radical 5 can be considered as an equivalent of the cyclization of 4-formylbutyl radical $\mathbf{1}$. In addition, through the radical-Brook rearrangement, the radical is relocated to the initial site of attack. Therefore, acylsilane can be re garded as a reagent equivalent of the geminal radical acceptor/radical donor synthon. ${ }^{11}$

Parallel to our study of acylsilanes, Curran developed the radical chemistry of acylgermanes (Scheme 3), ${ }^{12}$ In the acylgermane system, the cyclized $\alpha$-germyl alkoxy radical undergoes a $\beta$-scission reaction to obtain cyclic ketone with concomitant formation of a germyl radical which carries on the chain reaction. Reminiscent to the acylgermane system, $\mathrm{Kim}$ and $\mathrm{J}$ on ${ }^{13}$ recently reported the radical cyclization of thioesters and selenoesters (Scheme 4). Instead of a catalytic cycle as in the acylgermane system, the thioester and selenoester systems require the use of 1.1 equiv of hexabutylditin. The $\beta$-scission process involved in these reactions serves to drive the carbonyl cyclizations to the right-hand side. The added advantage of the acylgermane system is that it is tin free and the removal of the germanium byproduct is easy.

(8) (a) Tsai, Y.-M ; Cherng, C.-D. Tetrahedron Lett. 1991, 32, 3515. (b) Tsai, Y.-M.; Tang, K.-H.; J iaang, W.-T. Tetrahedron Lett. 1993, 34, 1303. (c) Curran, D. P.; j iaang, W.-T.; Palovich, M.; Tsai, Y.-M. Synlett 1993, 403. (d) Tsai, Y.-M.; Chang, S.-Y.J . Chem. Soc., Chem. Commun. 1995, 981. (e) Chuang, T.-H.; Fang, J .-M.; J iaang, W.-T.; Tsai, Y.-M. J . Org. Chem. 1996, 61, 1794. (f) Tsai, Y.-M.; Tang, K.-H.; J iaang, W.T. Tetrahedron Lett. 1996, 37, 7767. (g) Tsai, Y.-M.; Nieh, H.-C.; Pan, J.-S.; Hsiao, D.-D. J . Chem. Soc., Chem. Commun. 1996, 2469.

(9) (a) Dalton, J. C.; Borque, R. A. J . Am. Chem. Soc. 1981, 103, 699. (b) Harris, J. M.; Maclnnes, I.; Walton, J. C.; Maillard, B. J . Organomet. Chem. 1991, 403, C25. (c) Tsai, Y.-M.; Ke, B.-W. J . Chin. Chem. Soc. (Taipei) 1993, 40, 641. (d) Robertson, J .; Burrows, J . N. Tetrahedron Lett. 1994, 35, 3777.

(10) J ackson, R. A. J . Organomet. Chem. 1979, 166, 17.

(11) Ryu, I.; Sonoda, N.; Curran, D. P. Chem. Rev. (Washington, D.C.) 1996, 96, 177

(12) (a) Curran, D. P.; Liu, H. J . Org. Chem. 1991, 56, 3463. (b) Curran, D. P.; Palovich, M. Synlett 1992, 631. (c) Curran, D. P.; Diederichsen, U.; Palovich, M. J. Am. Chem. Soc. 1997, 119, 4797.

(13) Kim, S.; J on, S. Y. J . Chem. Soc., Chem. Commun. 1996, 1335.

\section{Scheme 4}
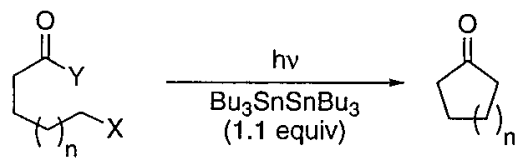

$\mathrm{n}=1$ or 2

$\mathrm{X}=\mathrm{Br}$ or $\mathrm{I}$

$Y=$ SPh or SePh

$$
\downarrow \mathrm{Bu}_{3} \mathrm{Sn} \text {. }
$$<smiles>[Y]C(=O)CCC(C)C(C)(C)C</smiles>

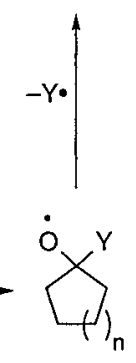

In the case of 5-hexenyl radical cyclization, it is wellknown that an alkyl substituent at C(5) severely reduces the rate of 5-exo cyclization.6,14 In comparison, a recent report by Curran, Diederichsen, and Palovich ${ }^{12 c}$ on radical cyclizations of acylgermanes showed that although the cyclization rate is dependent on the germanium ligand, the steric effect of the germyl group is not obvious for 5-exo cyclization. This may be attributed to the longer carbon-germanium bond. Therefore, it is important to determine the size effect of the silyl group of acylsilane toward the cyclization. The feasibility of the acylsilane cyclization using primary, secondary, aryl, and vinyl radicals is also studied and described in this full account.

\section{Results and Discussion}

Synthesis of Acylsilane Substrates. Retrosynthetically, radicals such as acylsilane $\mathbf{5}$ were generated from the corresponding haloacylsilanes using the tributyltin hydride methodology. The haloacylsilanes were synthesized using method developed by Brook and Corey. ${ }^{15,16}$ As shown in Table 1, 2-silyl-substituted 1,3-dithianes 8 were alkylated with suitable halides. The resulting aliphatic bromo 1,3-dithianes could not be stored for a long period due to the presence of a nucleophilic sulfur and electrophilic halide in the same molecule. ${ }^{17}$ Therefore, it is best to hydrolyze the crude alkylation product directly without delay. The use of red mercuric oxide and boron trifluoride etherate in wet THF for the hydrolysis of 1,3-dithiane was generally successful. ${ }^{18}$ However, when olefin was present as in entries 21-24, ceric ammonium nitrate (CAN) in wet acetonitrile ${ }^{19}$ was used instead to avoid complication due to the participation of the olefin in the reaction. ${ }^{20}$ In the cases with hindered silyl group as in dithianes $\mathbf{8} \mathbf{d}^{15 a}$ and $\mathbf{8 e}^{21}$ (entries 4, 5,

(14) Beckwith, A. L. J .; Blair, I. A.; Phillipou, G. Tetrahedron Lett. 1974, 2251.

(15) (a) Brook, A. G.; Duff, J . M.; J ones, P. F.; Davis, N. R. J . Am. Chem. Soc. 1967, 89, 431. (b) Corey, E. J .; Seebach, D.; Freedman, R. J . Am. Chem. Soc. 1967, 89, 434.

(16) F or reviews about acylsilanes, see: (a) Ricci, A.; Degl'I nnocenti, A. Synthesis 1989, 647. (b) Page, P. C. B.; Klair, S. S.; Rosenthal, S Chem. Soc. Rev. 1990, 19, 147. (c) Cirillo, P. F.; Panek, J . S. Org. Prep. Proc. Int. 1992, 24, 553.

(17) (a) Davey, A. E.; Parsons, A. F.; Taylor, R. J . K. J . Chem. Soc., Perkin Trans. 1 1989, 1853. (b) Sui, Z.; Furth, P. S.; De Voss, J . J . J . Org. Chem. 1992, 57, 6658.

(18) Vedejs, E.; Fuchs, P. L. J . Org. Chem. 1971, 36, 366

(19) (a) Ho, T.-L.; Ho, H. C.; Wong, C. M. J . Chem. Soc., Chem. Commun. 1972, 791. (b) Ho, H. C.; Ho, T.-L.; Wong, C. M. Can. J . Chem. 1972, 50, 2718.

(20) Tsai, Y.-M.; Nieh, H.-C.; Cherng, C.-D. J . Org. Chem. 1992, 57, 7010.

(21) Yoshida, J .; Itoh, M.; Matsunaga, S.; Isoe, S. J . Org. Chem. 1992, 57, 4877. 
Table 1. Preparation of (Haloacyl)silanes from 2-Silyl-1,3-dithianes

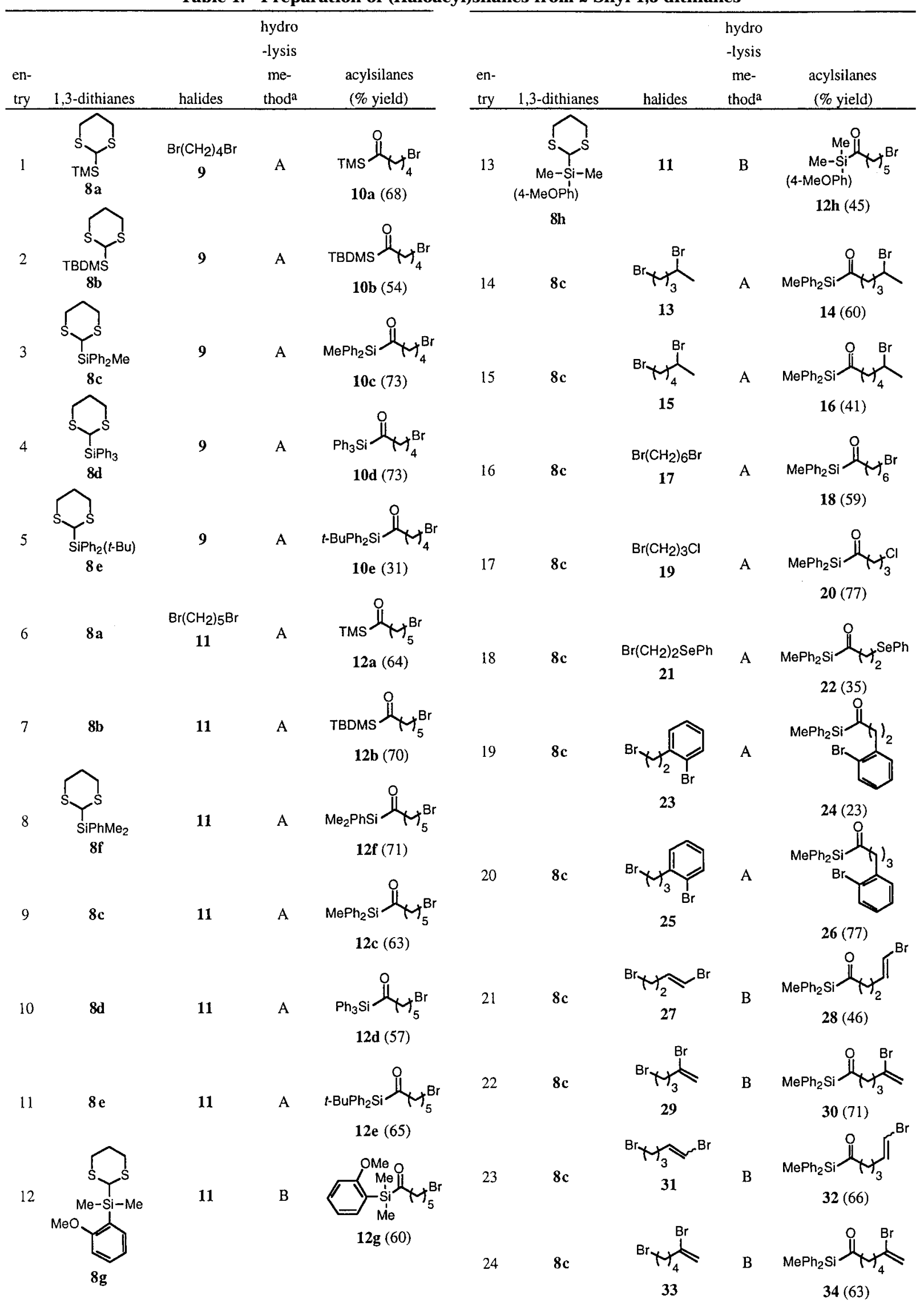

a Method A: red $\mathrm{HgO}$ (2 equiv), $\mathrm{BF}_{3} \cdot \mathrm{OEt}_{2}$ (2 equiv), $\mathrm{H}_{2} \mathrm{O} / \mathrm{THF}$ (15/85), rt, 1 h. Method B: CAN (3 equiv), $\mathrm{NaHCO}_{3}\left(1.5\right.$ equiv), $\mathrm{H}_{2} \mathrm{O}$ / $\mathrm{CH}_{3} \mathrm{CN}(1 / 8),-30{ }^{\circ} \mathrm{C}, 5 \mathrm{~min}$.

10 , and 11), the alkylations required the use of HMPA. In entries 19 and 21 , low yields of acylsilanes $\mathbf{2 4}^{\text {Be }}$ and
28 resulted from the elimination side reactions of dibromides $\mathbf{2 3}$ and $\mathbf{2 7}$ during alkylations. 
Table 2. Radical Cyclizations of Acylsilanes Involving Primary Radicalsa

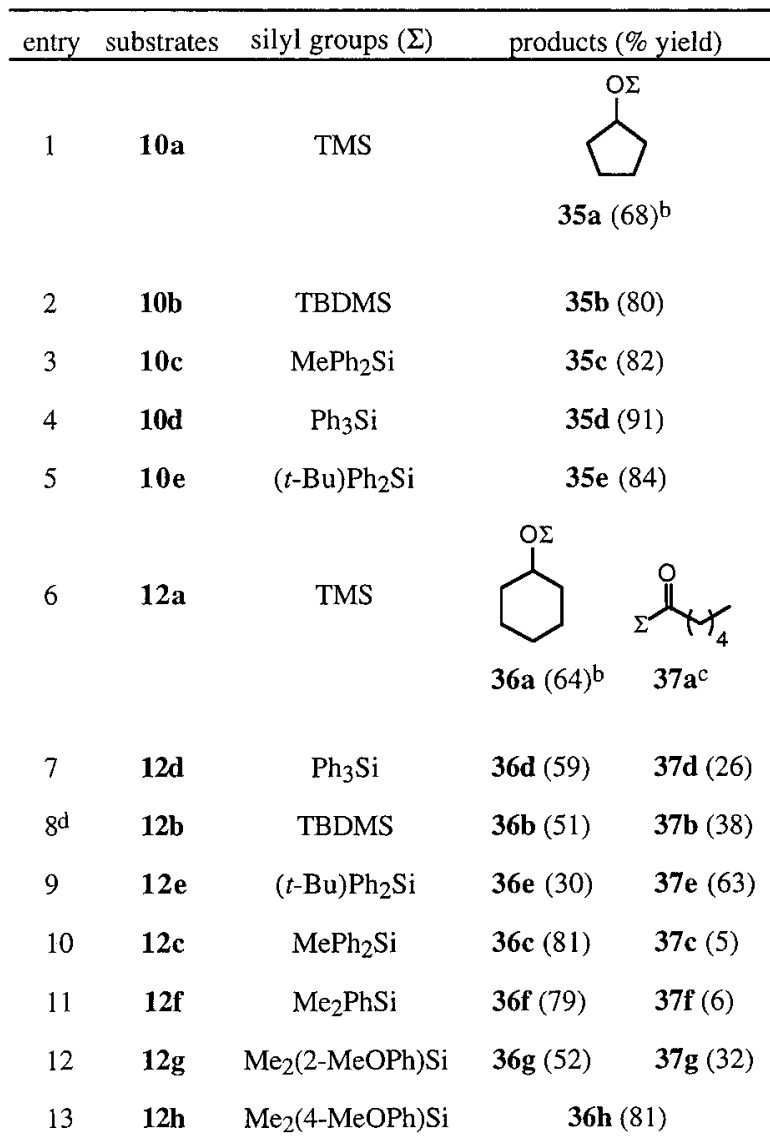

a The cyclization was performed by slow addition ( $6 \mathrm{~h}$ ) of a benzene solution of tributyltin hydride (1.2-1.5 equiv) and AIBN ( $5 \mathrm{~mol} \%$ ) to a refluxing solution of the substrate. Equal amounts of benzene were used to prepare the two solutions, and the final concentration relative to the substrate was $0.05 \mathrm{M}$. b The yield was extrapolated from the yield of the corresponding benzoate derived from the silyl ether. c The ratio of $\mathbf{3 6 a / 3 7 a}$ was determined to be $5.4 / 1$ by GC. ${ }^{d}$ The final concentration relative to $\mathbf{1 2 b}$ was 0.025 M.

Cyclizations Involving Alkyl Radicals. The radical cyclization studies were generally performed by slow addition $(6 \mathrm{~h})$ of a benzene solution of tributyltin hydride (1.2-1.5 equiv) and AIBN (0.05 equiv) to a refluxing benzene solution of bromoacylsilane. Our results involving primary radicals are shown in Table 2 . The results show that primary radicals undergo 5-exo cyclization very efficiently (entries 1-5). Variation of the size of the silyl group did not have a significant effect on this type of cyclizations. High yields were obtained, and we did not isolate any uncyclized reduction product. In the case of entry 1, we had difficulty isolating trimethylsilyl ether 35a because of its volatility. To overcome this problem, we directly added benzoyl chloride (5 equiv), TBAF/THF ( 2.5 equiv), and triethylamine (4 equiv) at the end of cyclization and heated the reaction mixture for $3 \mathrm{~h}$ at 80 ${ }^{\circ} \mathrm{C}$. In this way, we were able to isolate cyclopentyl benzoate in $68 \%$ yield. Therefore, the yield of 35 a should be at least $68 \%$. Gas chromatographic analysis of the cyclization mixture derived from acyltrimethylsilane $\mathbf{1 0 a}$ also showed that there was no uncyclized product. ${ }^{22}$

Contrary to 5-exo cyclizations, 6-exo cyclizations of primary radicals (entries $6-11$, Table 2 ) are more sensi-

(22) Authentic straight reduction product was obtained by alkylation of $\mathbf{8 a}$ with the corresponding alkyl bromide followed by hydrolysis. tive to the change of the silyl group. Similar to that mentioned above, the 6-exo cyclization of acyltrimethylsilane 12a gave the volatile cyclization product which was converted directly to cyclohexyl benzoate in $64 \%$ yield (entry 6). Therefore, the yield of cyclized silyl ether 36a should be at least of the same value. Careful analysis of the crude reaction mixture by GC showed the presence of reduction product 37a which was identified by comparison with an authentic sample prepared alternatively. ${ }^{22,24}$ The ratio of $\mathbf{3 6 a / 3 7 a}$ was determined to be $5.4 / 1$ by GC. In the cases of acyltriphenylsilane 12d (entry 7) and acyl(tert-butyl)dimethylsilane 12b (entry 8), substantial amounts of straight reduction products 37d (26\%) and 37b (38\%) were also obtained. With a very bulky tert-butyldiphenylsilyl group (entry 9), acylsilane $\mathbf{1 2 e}$ gave only $30 \%$ of cyclization product $\mathbf{3 6 e}$, and the major product was debrominated acylsilane 37e (63\%). Both acylsilanes $\mathbf{1 2 d}$ and $\mathbf{1 2 b}$ contain large silyl groups; however, the silyl groups are smaller than the tert-butyldiphenylsilyl group. ${ }^{23}$ On the basis of these observations, it is clear that for the 6-exo cyclizations of acylsilanes 12, as the size of the silyl group increases, the yield of the cyclization product decreases. Together, these results indicated that the rate of 6-exo cyclization of acylsilane is slower than that of the 5-exo cyclization.

The best two cases of this type are the cyclizations of acylsilanes $\mathbf{1 2} \mathbf{c}^{20}$ (entry 10 ) and $\mathbf{1 2 f}$ (entry 11 ). Both gave $\sim 80 \%$ of cyclized products $(\mathbf{3 6 c}, \mathbf{f})$ with $\sim 5 \%$ of reduction products (37c,f). As we have mentioned above the larger the size of the silyl group, the lower the yield of silyl ether 36. Assuming that the dimethylphenylsilyl and methyldiphenylsilyl groups are larger than the trimethylsilyl group, it is surprising that both acylmethyldiphenylsilane 12c (entry 10) and acyldimethyl phenyl silane 12f (entry 11) gave more cyclization products than acyltrimethylsilane 12a (entry 6). We speculate that the unexpected cyclization efficiency of $\mathbf{1 2 c}$ and $\mathbf{1 2 f}$ is due to the presence of the phenyl group on silicon. However, with the presence of three phenyl groups on silicon as in acyltriphenylsilane 12d (entry 7), the cyclization is less efficient due to the enhanced steric effect.

In the case of acyltriphenylgermanes, Curran, Diederichsen, and Palovich ${ }^{12 c}$ found that the 5-exo primary radical cyclization $\left(\mathrm{k}_{\mathrm{c}}=6.4 \times 10^{6} \mathrm{~s}^{-1}\right.$ at $\left.80^{\circ} \mathrm{C}\right)$ is faster than the 6-exo cyclization $\left(\mathrm{k}_{\mathrm{c}}=1.3 \times 10^{6} \mathrm{~s}^{-1}\right.$ at $\left.80^{\circ} \mathrm{C}\right)$. It was also reported that acylgermanes with triphenylgermyl group exhibit higher reactivity than those with nonaromatic germanium ligands. This was attributed to a lower carbonyl LUMO energy of acyltriphenylgermanes. ${ }^{12 c}$ The results of the cyclizations of acylsilanes shown in Table 2 are consistent with the acylgermane chemistry. However, acyltriphenylsilane 12d (entry 7) does not cyclize as efficiently as the corresponding acyltriphenylgermane ${ }^{12 c}$ (87\% cyclization).

When the phenyl group on silicon contains an ortho substituent as in acylsilane $\mathbf{1 2 g}$ (entry $\mathbf{1 2}$ ), the cydization also is less efficient. An appreciable amount of straight reduction product $\mathbf{3 7 g}$ (32\%) was obtained along with $52 \%$ of cyclized product $\mathbf{3 6 g}$. In the case of acylsilane 12h (entry 13) with a 4-methoxy group attached on the phenyl group, the cyclization gave silyl ether 36h (81\%) exclusively. This result was similar to the cyclization of acyldimethylphenylsilane $\mathbf{1 2 f}$ (entry 11). Ther efore, the

(23) Hwu, J . R.; Wang, N. Chem. Rev. (Washington, D.C.) 1989, 89 1599.

(24) Miller, J . A.; Zweifel, G. Synthesis 1981, 288. 
Table 3. Radical Cyclizations of Acylsilanes Involving Secondary Radicals ${ }^{a}$

\begin{tabular}{|c|c|c|c|c|c|}
\hline entry & substrate & $\begin{array}{c}\text { concentration } \\
(\mathrm{M})^{\mathrm{b}} \\
\end{array}$ & $\begin{array}{l}\text { addition time } \\
\text { of } \mathrm{Bu}_{3} \mathrm{SnH}(\mathrm{h})\end{array}$ & $\begin{array}{c}\text { cyclization } \\
\text { products (\% yield) }\end{array}$ & $\begin{array}{l}\text { straight reduction } \\
\text { product (\% yield) }\end{array}$ \\
\hline 1 & 14 & 0.05 & 6 & $\square_{38(76)^{c}}$ & - \\
\hline 2 & 14 & 0.5 & 0.5 & $38(80)^{c}$ & - \\
\hline $3^{d}$ & 14 & 0.5 & - & $38(94)^{c}$ & $37 \mathrm{c}(5)$ \\
\hline 4 & 16 & 0.5 & 0.5 & - & $\underset{39(76)}{\mathrm{MePh}_{2} \mathrm{Si}^{-1} \mathrm{HY}_{5}}$ \\
\hline 5 & 16 & 0.02 & 2 & $40(51)^{\mathrm{e}}$ & $39(42)$ \\
\hline 6 & 16 & 0.009 & 2 & $40(57)^{\mathrm{e}}$ & $39(39)$ \\
\hline
\end{tabular}

\begin{abstract}
a The cyclization was performed by slow addition of a benzene solution of tributyltin hydride (1.2-1.3 equiv) and AIBN (5 mol \%) to a refluxing benzene solution of the substrate. ${ }^{b}$ The final concentration relative to the substrate. ${ }^{c} A$ separable mixture of cis and trans isomers, cis/ trans $=55 / 45$. d The reaction was performed by directly mixing the substrate, stannane, and AIBN in benzene and heated to reflux for $0.5 \mathrm{~h}$. e A separable mixture of cis and trans isomers, cis/ trans $=3 / 7$.
\end{abstract}

sluggish cyclization of $\mathbf{1 2} \mathbf{g}$ is more likely due to the steric effect of the ortho substituent and not to the electronic effect.

5-Exo radical cyclizations of acylsilanes with secondary radicals were also studied (Table 3 ). Under the same condition as used in Table 2, acylsilane $\mathbf{1 4}$ (entry 1, Table 3) gave silyl ether 38 in 76\% yield. Compared with the cyclization of the primary substrate 10c (Table 2, entry 3), no apparent difference between the primary and secondary substrate is observed. We found that this reaction could be performed in a concentrated condition (0.5 $\mathrm{M}$ in benzene). When the tributyltin hydride solution was quickly added over $0.5 \mathrm{~h}$, acylsilane 14 still gave silyl ether 38 (80\%) as the only product (entry 2). Even when we mixed 14 (0.5 $\mathrm{M}$ in benzene), tributyltin hydride, and AIBN (5 mol \%) directly and heated for 0.5 h (entry 3), we were able to isolate $52 \%$ of cis-38, $42 \%$ of trans-38, and only $5 \%$ of straight reduction product 37c. These experiments demonstrate that the 5-exo cyclization of acylsilane can be performed very practically with a fairly concentrated condition in a short time.

In contrast to the 5-exo cyclization of acylsilane 14 (entry 2), the homologous acylsilane 16 (entry 4) gave only straight reduction product 39 (76\%). N ote that the conditions used in entries 2 and 4 were the same. We had to dilute the concentration and lengthen the stannane addition time (entries 5 and 6) to obtain the cyclization product. Thus, in entry 6 we were able to isolate $17 \%$ of silyl ether cis- $\mathbf{4 0}, \mathbf{4 0 \%}$ of trans-40, and $39 \%$ of reduction product 39 . Compared with the 6-exo cyclization of the primary substrate 12c (entry 10, Table 2 ), the cyclization of the secondary substrate $\mathbf{1 6}$ is less efficient. Therefore, the 6-exo cyclization of acylsilane is sensitive not only to the size of the silyl group but also to the substituent at the carbon bearing the initial radical. A similar trend was also observed in the acylgermane system. ${ }^{12 c}$ This is contrary to the 5-hexenyl radical cyclization system which is less sensitive to the substituents at $\mathrm{C}(1)$. 6,14

To determine the stereochemistry of the cyclized fivemembered ring product 38, we started from the commercially available trans-alcohol $\mathbf{4 1}$ and prepared an authentic sample of silyl ether trans-38 via a well-known method $^{25}$ (eq 1). Ther efore, the stereochemical structure

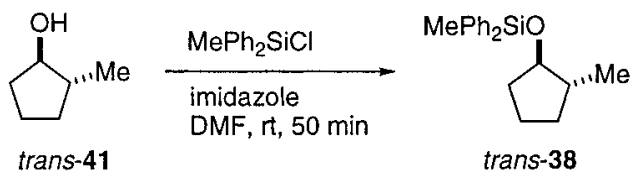

of trans-38 was identified. ${ }^{13} \mathrm{C} \mathrm{NMR}\left(\mathrm{CDCl}_{3}\right)$ absorption of the methyl carbon in trans-38 appeared at $\delta 18.1$ and that of cis-38 appeared at $\delta$ 14.5. The higher field absorption of the methyl carbon of cis-38 indicated that the methyl group was located at a sterically more encumbered position. ${ }^{26}$

In the ${ }^{1} \mathrm{H} \mathrm{NMR}\left(\mathrm{CDCl}_{3}\right)$ spectra of six-membered ring silyl ether 40, the hydrogen absorption at C-1 appeared at $\delta 3.75-3.90(\mathrm{~m}, \mathrm{OCH})$ for cis-40 and $\delta 3.24(\mathrm{td}, \mathrm{J}=$ $10.0,4.0 \mathrm{~Hz}, \mathrm{OCH})$ for trans-40. These values correlate reasonably well with those of cis- and trans-2-methylcyclohexanol ( $\delta 3.82$ for the cis-isomer and $\delta 3.10$ for the trans-isomer). ${ }^{27}$ In particular, the coupling pattern for $\mathrm{C}(1)-\mathrm{H}$ of trans-40 indicated that it belongs to the transdiequatorial conformer. In the ${ }^{13} \mathrm{C}$ NMR spectra of $\mathbf{4 0}$, the methyl carbon of cis-40 appeared at $\delta \mathbf{1 7 . 6}$ and that of trans-40 appeared at $\delta$ 19.3. Similar to silyl ether 38, the methyl carbon of cis-40 appeared at higher field.

(25) Corey, E. J .; Venkateswarlu, A. J . Am. Chem. Soc. 1972, 94 6190.

(26) Breitmaier, E.; Voelter, W. Carbon-13 NMR Spectroscopy; 3rd ed.; VCH: Weinhein, 1990; p 115.

(27) I guchi, S.; Nakai, H.; Hayashi, M.; Yamamoto, H.; Maruoka, K. Bull. Chem. Soc. J pn. 1981, 54, 3033. 
Table 4. Radical Cyclizations of Acylsilanes in the Presence of $\mathrm{Et}_{3} \mathrm{~B}^{\mathrm{a}}$

\begin{tabular}{|c|c|c|c|c|}
\hline entry & substrates & $\begin{array}{c}\text { amount of } \\
E_{3} B \text { (equiv) }\end{array}$ & $\begin{array}{l}\text { temp } \\
\left({ }^{\circ} \mathrm{C}\right) \\
\end{array}$ & $\begin{array}{l}\text { products } \\
\text { (ratio) }^{\mathrm{d}}\end{array}$ \\
\hline $\begin{array}{l}1^{b} \\
2 \\
3^{e} \\
4 \\
5^{e} \\
6 \\
7\end{array}$ & $\begin{array}{l}12 a \\
12 a \\
12 b \\
12 b \\
12 b \\
12 b \\
12 c\end{array}$ & $\begin{array}{l}0^{c} \\
1.3 \\
0^{c} \\
1.2 \\
0^{c} \\
1.5 \\
0.18\end{array}$ & $\begin{array}{l}80 \\
\mathrm{rt} \\
80 \\
\mathrm{rt} \\
\mathrm{rt} \\
80 \\
\mathrm{rt}\end{array}$ & $\begin{array}{l}\text { 36a/37a }(5.4 / 1) \\
\text { 36a/37a }(36 / 1) \\
\text { 36b/37b (1.6/1) } \\
\text { 36b/37b }(4.4 / 1) \\
\text { 36b/37b (0.85/1) } \\
\text { 36b/37b }(2.2 / 1) \\
\text { 36 } \mathbf{c}^{9}\end{array}$ \\
\hline
\end{tabular}

${ }^{a} \mathrm{~A}$ benzene solution of tributyltin hydride (1.3 equiv) was added over $2 \mathrm{~h}$ to a benzene solution of the substrate and triethyl borane. The final concentration relative to the substrate was $0.05 \mathrm{M}$. Dry air was slowly bubbled through the reaction mixture via a syringe. $\mathrm{b}$ The reaction condition described in Table 2 was used. ${ }^{\mathrm{C}} \mathrm{AIBN}$ was used for initiation. ${ }^{d}$ The ratio was determined by GC. ${ }^{e} A$ benzene solution of tributyltin hydride (1.2 equiv) and AIBN (5 mol \%) was slowly added over $2 \mathrm{~h}$ to a benzene solution of the substrate. The final concentration relative to the substrate was $0.05 \mathrm{M}$. The reaction mixture was irradiated with two $100 \mathrm{~W}$ tungsten lamps. ${ }^{f}$ U nreacted $\mathbf{1 2 b}$ (32\%) was observed. 9 Straight reduction product was not observed.

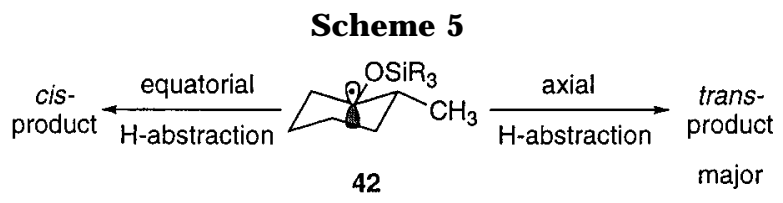

The stereochemical outcome of the cyclizations of acylsilanes $\mathbf{1 4}$ and $\mathbf{1 6}$ is determined at the hydrogen abstraction step. As shown in Scheme 5, the cyclization of $\mathbf{1 6}$ went through $\alpha$-silyloxy radical $\mathbf{4 2}$ in which the methyl group preferred to adopt an equatorial position. It is well-known that the cyclohexyl radical prefers to abstract hydrogen from the axial site. ${ }^{28}$ Therefore, axial hydrogen abstraction of radical $\mathbf{4 2}$ should give the transproduct preferentially as observed.

Effect of Triethylborane. Clive and Postema ${ }^{2 j}$ re cently reported that triethylborane-stannane-air system $^{29}$ could improve the cyclization of 5-formylpentyl radical (3) system. On the basis of their finding, we performed radical cyclization of acylsilanes using triethylborane-air for initiation. As shown in Table 4, without triethylborane the cyclization of the primary 6-exo substrate $12 \mathrm{a}$ at $80^{\circ} \mathrm{C}$ gave cyclization product 36a/reduction product $37 a^{24}$ in a ratio of $5.4 / 1$ by GC analysis (entry 1). When the triethylborane method ( $r t$ ) was used (entry 2 ), the ratio of $\mathbf{3 6 a / 3 7 a}$ improved to 36/1. Likewise, in the case with a tert-butyldimethylsilyl group the ratio of $\mathbf{3 6} \mathbf{b} / \mathbf{3 7} \mathbf{b}^{30}$ obtained from acylsilane $\mathbf{1 2 b}$ (entries 3 and 4) also increased. When acylmethyldiphenylsilane 12c was cyclized using the triethyl bor ane method at rt (entry 6), we did not observe reduction product 37c by GC.

To determine whether this improvement was due to the temperature or not, we performed the cyclization of 12b at room temperature without triethyl borane (entry 5). This reaction was initiated by the irradiation of two $100 \mathrm{~W}$ tungsten lamps in the presence of AIBN $(5 \mathrm{~mol}$ $\%)$. The ratio of cyclization product $36 \mathbf{b}$ /reduction product $\mathbf{3 7 b}$ was $0.85 / 1$. This result indicated that the use of triethylborane is hel pful for cyclization. Interestingly,

(28) (a) Curran, D. P.; Porter, N. A.; Giese, B. Stereochemistry of Radical Reactions; VCH: Weinheim, 1996; Chapter 3. (b) Giese, B. Angew. Chem., Int. Ed. Engl. 1989, 28, 969.

(29) (a) Nozaki, K.; Oshima, K.; Utimoto, K. J . Am. Chem. Soc. 1987 109, 2547. (b) Miura, K.; Ichinose, Y.; N ozaki, K.; Fugami, K.; Oshima, K.; Utimoto, K. Bull. Chem. Soc. J pn. 1989, 62, 143 .

(30) Dondy, B.; Doussot, P.; Portella, C. Synthesis 1992, 995. comparison of the reactions at room temperature (entry 5 ) and $80^{\circ} \mathrm{C}$ (entry 3) showed that without triethylborane the cyclization process is preferred at higher temperature. However, when we performed the cydization of $\mathbf{1 2 b}$ (entry 5) at $80^{\circ} \mathrm{C}$ using triethylborane-air for initiation, we found only a slight increase in the ratio of $\mathbf{3 6 b} / \mathbf{3 7 b}$ (cf. entry 3). Therefore, the beneficial effect of triethyl borane seems to operate only at lower temperature. The influence of triethylborane is small at higher temperature.

Attempted Formation of Other Ring Sizes and Intermolecular Process. To test if this method could be used to construct rings other than five- and sixmembered, we examined the cyclization of acylsilanes 18, 20, and $\mathbf{2 2}$ (entries 16-18, Table 1). The chloride 20 and selenide $\mathbf{2 2}$ were used because we were not able to synthesize the corresponding bromides using the 1,3dithiane strategy. Treatment of the 7-exo substrate $\mathbf{1 8}$ with tributyltin hydride (1.6 equiv) gave $68 \%$ of reduction product 39 and $23 \%$ of $\alpha$-silyl al cohol $\mathbf{4 3}$. Alcohol $\mathbf{4 3}$ was presumably derived from further reduction of acylsilane 39 with excess stannane. ${ }^{31}$ The reaction of the 4-exo substrate 20 with tributyltin hydride (1.65 equiv) gave $34 \%$ of reduction product $\mathbf{4 4}, \mathbf{1 3 \%}$ of chloride $\mathbf{4 5}, 5 \%$ of silyl ether $\mathbf{4 6}$, and $\mathbf{3 0} \%$ of recovered $\mathbf{2 0}$. The presence of chloride $\mathbf{4 5}$ indicated that the rate of acylsilane carbonyl reduction by stannane is competitive to the reduction of the chloride moiety. ${ }^{31,32}$ We do not know the origin of the silyl ether 46. The reaction of the 3-exo substrate 22 with tributyltin hydride (1.3 equiv) gave $79 \%$ of reduction product 47. Therefore, the formation of unsubstituted seven-, four- and three-membered rings is not feasible using this method.
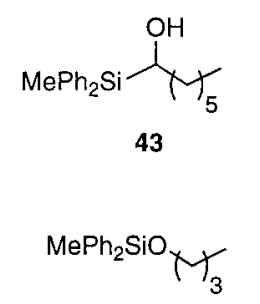

46
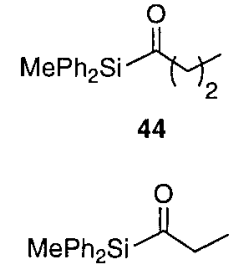

47

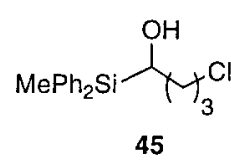<smiles>CC(=O)CS(C)(=O)=O</smiles>

48
We also examined the possibility of intermolecular coupling of alkyl radical with acylsilane. This was performed by slow addition ( $0.5 \mathrm{~h}$ ) of a benzene solution of tributyltin hydride (1.2 equiv) and AIBN ( $5 \mathrm{~mol} \%$ ) to a refluxing benzene solution of 5 equiv of acetyltrimethylsilane (48) and hexadecyl bromide. The final concentration relative to the bromide was $0.5 \mathrm{M}$. Unfortunately, we did not observe any coupling product. The ${ }^{1} \mathrm{H} N M R$ of the crude concentrate of the reaction mixture showed that the hexadecyl bromide was completely reduced with the acylsilane $\mathbf{4 8}$ left intact.

Cyclizations with Aryl Radicals. An aryl radical is potentially more reactive than an alkyl radical. However, for intramolecular cyclization involving an aryl radical, the two $\mathrm{sp}^{2}$ centers of the aryl group incorporated in the forming ring may increase the strain energy for cyclization. ${ }^{33}$ Therefore, it is essential to test the acylsilane system with an aryl radical.

(31) Ingold, K. U.; Lusztyk, J .; Scaiano, J . C. J . Am. Chem. Soc. 1984, 106, 343

(32) Beckwith, A. L. J .; Pigou, P. E. Aust. J . Chem. 1986, 39, 77.

(33) Beckwith, A. L. J .; Gara, W. B. J . Chem. Soc., Perkin Trans. 2 1975, 795. 
Scheme 6
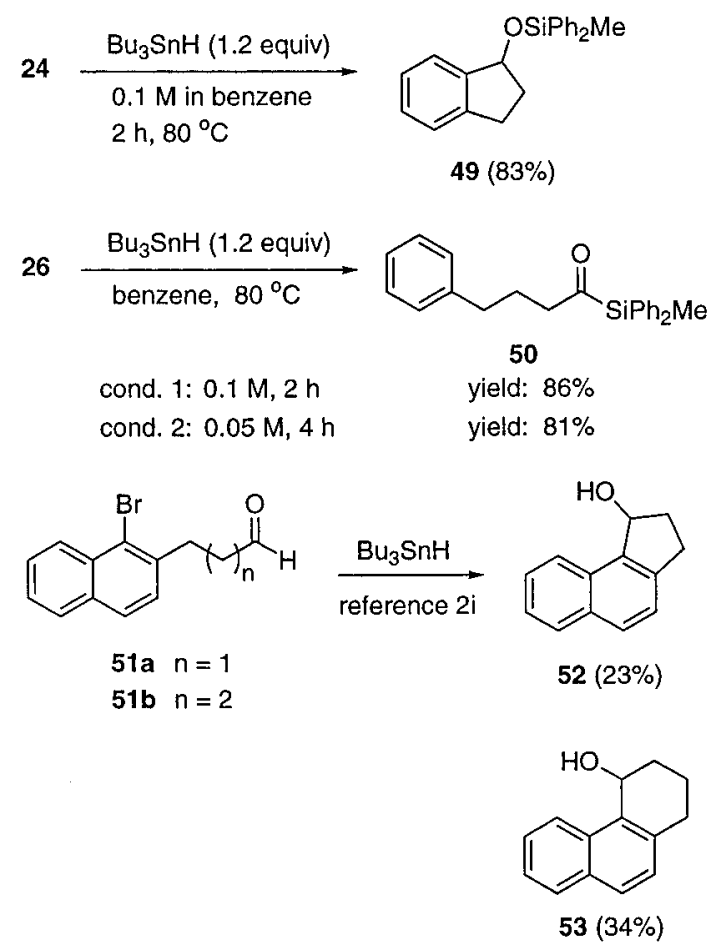

As shown in Scheme 6, the 5-exo substrate $\mathbf{2 4}^{8 \mathrm{e}}$ cyclized effectively when treated with tributyltin hydride and gave silyl ether $\mathbf{4 9}$ in $\mathbf{8 3} \%$ yield. On the contrary, under the same condition (condition 1) the homologous acylsilane $\mathbf{2 6}$ gave only reduction product $\mathbf{5 0}$ (86\%). Even when we lengthened the stannane addition rate to $4 \mathrm{~h}$ (condition 2) and made the concentration more dilute $(0.05 \mathrm{M})$, we still obtained acylsilane $\mathbf{5 0}$ in $81 \%$ yield without the formation of 6-exo cyclization product. Previously, we noted that 1,5-hydrogen transfer involving the carbonyl $\alpha$-hydrogen is a potential side reaction in our 6-exo cyclization system. ${ }^{8 b}$ The 1,5-hydrogen transfer process in $\omega$-formylalkyl radical cyclizations ${ }^{5 b}$ and acylgermane cyclizations ${ }^{12 c}$ has al so been reported. We believed that this might be the major process for the attempted cyclization of 26. Grissom et al. ${ }^{2 i}$ recently reported the cyclizations of aldehydes 51 . The 5-exo cyclization product $\mathbf{5 2}$ was obtained in $23 \%$ yield from al dehyde 51 a. The acylsilane system provides an attractive alternative for the 5-exo cyclization. However, the acylsilane system is worse for 6-exo cyclization involving an aryl radical because the corresponding aldehyde $\mathbf{5 1 b}$ gave $34 \%$ of 6-exo cyclization product $\mathbf{5 3}$ whereas acylsilane $\mathbf{2 6}$ gave only reduction product.

Cyclizations with Vinyl Radicals. Acylsilane cydization involving a vinyl radical ${ }^{34}$ provides an intriguing situation. First, there are two types of possible system. The exocyclic type (Scheme 7) having the vinyl group exocyclic to the forming ring involves one $\mathrm{sp}^{2}$ center of the vinyl group in the forming ring. The endocyclic type having the vinyl group endocyclic to the forming ring incorporates two $\mathrm{sp}^{2}$ centers of the vinyl group in the forming ring. Apparently, the degree of strain involved in these two systems is different. Second, cyclization followed by silyl shift provides an allylic radical as in $\mathbf{5 4}$ and 57. Hydrogen abstractions of these allylic radicals are confronted with regioselectivity options. Either enol

(34) (a) Stork, G.; Baine, N. H. J . Am. Chem. Soc. 1982, 104, 2321. (b) Stork, G.; Mook, R., J r. J . Am. Chem. Soc. 1983, 105, 3720.

\section{Scheme 7}

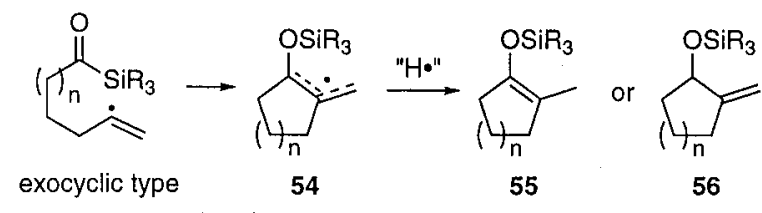

$n=1$ or 2

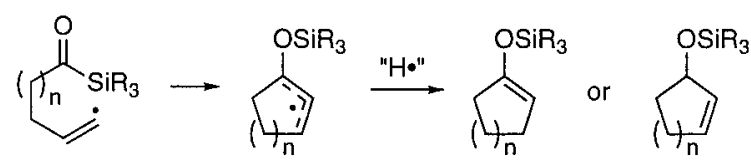

endocyclic type

57

58

59

\section{Scheme 8}
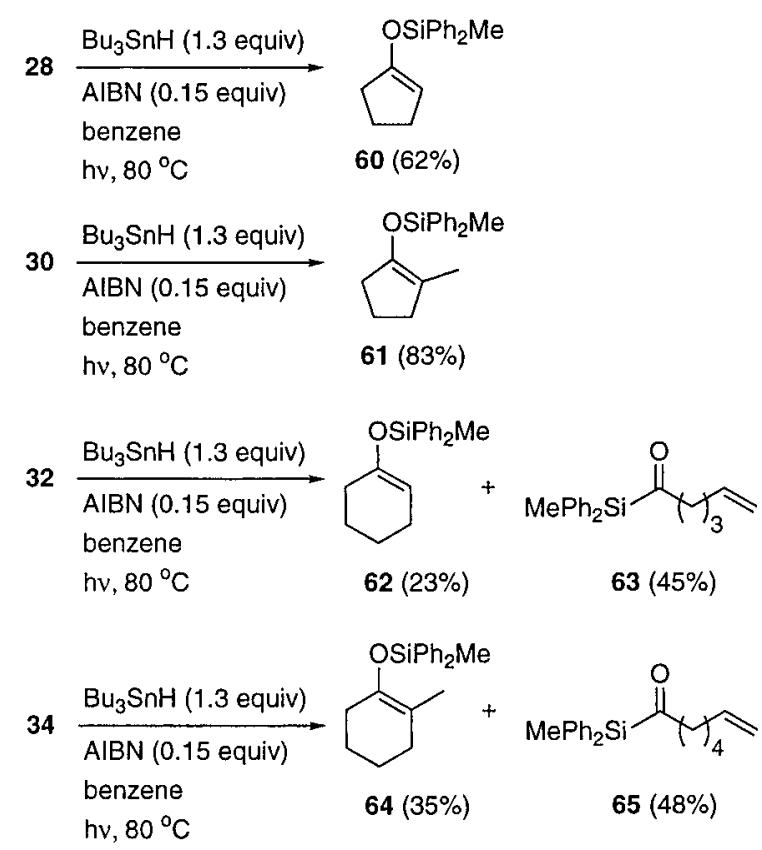

silyl ethers (55 and $\mathbf{5 8}$ ) or allyl silyl ethers (56 and 59) may be obtained.

Our cyclization results of vinyl radicals are summarized in Scheme 8. Initially, we had problems initiating the reaction by just heating. Therefore, we increased the amount of AIBN to $15 \mathrm{~mol} \%$ and irradiated the reaction mixture with two $100 \mathrm{~W}$ tungsten lamps. ${ }^{34}$ The two 5-exo cyclization systems $\mathbf{2 8}$ and $\mathbf{3 0}$ gave only cyclization products. More importantly, both cases gave regioselectively the enol silyl ethers $\mathbf{6 0}^{35}(62 \%)$ and $\mathbf{6 1}$ (83\%). Therefore, the intermediate allyl radicals prefer to abstract hydrogen at the less substituted carbon. This approach provides a unique way to prepare five-membered cyclic silyl enol ether regiospecifically. ${ }^{8 d}$

The two 6-exo cyclization systems $\mathbf{3 2}$ and $\mathbf{3 4}$ behave similarly and gave low yields of enol silyl ethers $\mathbf{6 2}^{36}$ (23\%) and 64 (35\%). Reduction products 63 (45\%) and $65(48 \%)$ were obtained as the major products. Presumably, 1,5-hydrogen transfer is a major competing process.

\section{Conclusions}

Acylsilanes that bear a bromo substituent at the $\delta$ and $\epsilon$ position could be easily prepared. Intramolecular

(35) Leigh, W. J .; Bradaric, C. J .; Sluggett, G. W. J . Am. Chem. Soc 1993, 115, 5332.

(36) Denmark, S. E.; Hammer, R. P.; Weber, E.J .; Habermas, K. L. J . Org. Chem. 1987, 52, 165. 
radical cyclizations of these bromoacylsilanes were most effective for 5-exo cyclizations. F or 6-exo cyclizations, the system was sensitive to the changes of the size of the silyl group and to the type of the initial radical center. 6-E xo cyclizations involving primary radicals were most effective when the silyl group was a methyldiphenylsilyl group. However, when a secondary radical was involved in 6-exo cyclization, only a moderate yield of cyclization product was obtained. Using triethylborane-air for initiation at room temperature al so improved the cyclization efficiency. An aryl radical underwent 5-exo cyclization with acylsilane successfully. In contrast, the 6-exo cyclization did not occur for an aryl radical. Vinyl radicals underwent 5-exo cyclizations with acylsilanes successfully and afforded enol silyl ethers as the products. The corresponding 6-exo cyclizations only gavelow yields of cyclization products.

The radical-Brook rearrangement involved in the acylsilane cyclizations not only serves to drive the reaction toward the cyclization side but also converts the cyclized oxygen radical to a carbon radical. This unique feature makes the acylsilane systems different from the $\omega$-formylalkyl radical cyclization systems. In the latter systems cyclic alcohols are the expected products, while in the former systems silyl group protected cyclic alcohols are obtained. In more functionalized cases such as the vinyl radical cyclizations of acylsilanes, regiospecific enol silyl ethers are accessible. This type of product cannot be obtained easily via the $\omega$-formylalkyl radical cyclizations. The cyclizations of acylsilanes are similar to acylgermanes in many respects. However, the two processes lead to different end products and are complementary. The acylgermanes cyclize to give cydic ketones, and the reaction stops at the ketone stage. ${ }^{12}$ The acylsilane cyclizations lead to a cyclized $\alpha$-silyloxy radical and create opportunities for further manipulations. ${ }^{8}$

\section{Experimental Section}

Melting points are uncorrected. ${ }^{1} \mathrm{H}$ NMR spectra were recorded at 200 or $300 \mathrm{MHz} ;{ }^{13} \mathrm{C} \mathrm{NMR}$ spectra were recorded at 50 or $75 \mathrm{MHz}$. Tetramethysilane $(\delta=0 \mathrm{ppm})$ or $\mathrm{CHCl}_{3}(\delta$ $=7.24 \mathrm{ppm}$ ) were used as internal standards, and $\mathrm{CDCl}_{3}$ was used as the solvent. Benzene and THF were distilled from sodium benzophenone ketyl under $\mathrm{N}_{2}$. HMPA was distilled over calcium hydride. The benzene used for cyclization reactions was deoxygenated by passing a gentle stream of argon through for $0.5 \mathrm{~h}$ before use. All reactions were performed under a blanket of $\mathrm{N}_{2}$ or Ar. Dibromides $\mathbf{2 3},{ }^{37} \mathbf{2 5},{ }^{38}$ $\mathbf{2 7}, 39 \mathbf{2 9}, 40 \mathbf{3 1}, 39$ and $\mathbf{3 3}^{40}$ were synthesized according to literature methods.

2-(Methyldiphenylsilyl)-1,3-dithiane (8c). To a solution of $2.00 \mathrm{~g}$ (16.7 mmol) of 1,3-dithiane in $16 \mathrm{~mL}$ of dry THF cooled at $0{ }^{\circ} \mathrm{C}$ was added dropwise over $20 \mathrm{~min}$ a solution of $1.60 \mathrm{M}$ of $\mathrm{n}$-butyllithium in hexane $(11.0 \mathrm{~mL}, 17.6 \mathrm{mmol})$. The resulting solution was stirred at $0{ }^{\circ} \mathrm{C}$ for $20 \mathrm{~min}$ followed by the addition of $3.51 \mathrm{~mL}(16.7 \mathrm{mmol})$ of chlorodimethylphenylsilane in one portion. The resulting mixture was stirred at 0 ${ }^{\circ} \mathrm{C}$ for $10 \mathrm{~min}$ and then at $\mathrm{rt}$ for $30 \mathrm{~min}$ and partitioned between $70 \mathrm{~mL}$ of ether and $25 \mathrm{~mL}$ of water. The ether phase was washed with brine $(25 \mathrm{~mL})$, dried $\left(\mathrm{MgSO}_{4}\right)$, and concentrated in vacuo. The residual liquid was chromatographed over silica gel (eluted with hexane/ethyl acetate, 98/2) to give $3.70 \mathrm{~g}(70 \%)$ of $8 \mathrm{c}$ as a white solid: $\mathrm{mp} 44-46{ }^{\circ} \mathrm{C} ;{ }^{1} \mathrm{H}$ NMR

(37) Ponton, J ;; Helquist, P.; Conrad, P. C.; Fuchs, P. L. J . Org. Chem. 1981, 46, 118.

(38) Rowley, L. E.; Swan, J. M. Aust. J . Chem. 1974, 27, 801

(39) Bestmann, H. J .; Zeibig, T.; Vostrowsky, O. Synthesis 1990, 1039.

(40) Shi, L.; Narula, C. K.; Mak, K. T.; Kao, L.; Xu, Y.; Heck, R. F. J. Org. Chem. 1983, 48, 3894.
(200 MHz) $\delta 0.73(\mathrm{~s}, 3 \mathrm{H}), 1.91-2.19(\mathrm{~m}, 2 \mathrm{H}), 2.69(\mathrm{dt}, \mathrm{J}=$ $14.0,4.0 \mathrm{~Hz}, 2 \mathrm{H}), 2.89(\mathrm{td}, \mathrm{J}=14.0,4.0 \mathrm{~Hz}, 2 \mathrm{H}), 4.20(\mathrm{~s}, 1$ $\mathrm{H}), 7.28-7.49(\mathrm{~m}, 6 \mathrm{H}), 7.55-7.71(\mathrm{~m}, 4 \mathrm{H}) ;{ }^{13} \mathrm{C}$ NMR $(50 \mathrm{MHz})$ $\delta-5.5,26.0,31.4,32.8,127.8,129.9,133.3,135.1$. Anal. Calcd for $\mathrm{C}_{17} \mathrm{H}_{20} \mathrm{~S}_{2} \mathrm{Si}$ : C, 64.50; $\mathrm{H}, 6.37$. Found: $\mathrm{C}, 64.34 ; \mathrm{H}, 6.57$.

2-(tert-Butyldiphenylsilyl)-1,3-dithiane (8e). To a solution of $600 \mathrm{mg}$ ( $5.00 \mathrm{mmol})$ of 1,3-dithiane in $5 \mathrm{~mL}$ of dry THF cooled in a dry ice-acetone bath was added dropwise over 20 min a solution of $1.50 \mathrm{M}$ of n-butyllithium in hexane $(3.60 \mathrm{~mL}$, $5.40 \mathrm{mmol}$ ). The resulting solution was stirred at the same temperature for $20 \mathrm{~min}$ followed by the addition of $1.75 \mathrm{~mL}$ (10.0 mmol) of HMPA. The resulting solution was stirred for another $30 \mathrm{~min}$ at the same temperature followed by slow addition of $1.44 \mathrm{~mL}(5.50 \mathrm{mmol})$ of tert-butylchlorodiphenylsilane over $20 \mathrm{~min}$. The resulting mixture was warmed slowly to room temperature and then stirred overnight. The reaction mixture was partitioned between $100 \mathrm{~mL}$ of ether and $100 \mathrm{~mL}$ of water. The organic layer was washed with water $(100 \mathrm{~mL})$ and brine $(50 \mathrm{~mL})$, dried $\left(\mathrm{MgSO}_{4}\right)$, and concentrated in vacuo. The residual oil was chromatographed over silica gel (eluted with hexane/ethyl acetate, 98/2) to give $1.35 \mathrm{~g}(75 \%)$ of $\mathbf{8 e}$ as a white solid: $\mathrm{mp} 113.5-115.0^{\circ} \mathrm{C}(\mathrm{EtOH}) ;{ }^{1} \mathrm{H}$ NMR $(200 \mathrm{MHz})$ $\delta 1.18(\mathrm{~s}, 9 \mathrm{H}), 2.00-2.15(\mathrm{~m}, 2 \mathrm{H}), 2.70(\mathrm{dt}, \mathrm{J}=14.0,3.6 \mathrm{~Hz}$, $2 \mathrm{H}), 2.78-3.05(\mathrm{~m}, 2 \mathrm{H}), 4.32(\mathrm{~s}, 1 \mathrm{H}), 7.35-7.48(\mathrm{~m}, 6 \mathrm{H})$, 7.68-7.85 (m, $4 \mathrm{H}) ;{ }^{13} \mathrm{C}$ NMR $(75 \mathrm{MHz}) \delta 19.2,26.0,28.5,32.0$, $32.7,127.3,129.4,132.0,136.2$; HRMS calcd for $\mathrm{C}_{20} \mathrm{H}_{26} \mathrm{~S}_{2} \mathrm{Si}$ $\mathrm{m} / \mathrm{z}$ 358.1245, found 358.1256.

2-[(2-Methoxyphenyl)dimethylsilyl]-1,3-dithiane (8g). To a mixture of $290 \mathrm{mg}$ (12.0 mmol) of magnesium turnings and $2 \mathrm{~mL}$ of THF was added a small amount of iodine and 2-bromoanisole. When the reaction was initiated, an additional portion of THF $(8 \mathrm{~mL})$ was added. A solution of 1.25 $\mathrm{mL}(10.0 \mathrm{mmol})$ of 2-bromoanisole in $10 \mathrm{~mL}$ of THF was added slowly to the above mixture in a rate as to keep a gentle reflux. The resulting mixture was stirred for another hour at room temperature and then added slowly to a solution of $6.3 \mathrm{~mL}$ ( $50 \mathrm{mmol})$ of dichlorodimethylsilane in $20 \mathrm{~mL}$ of THF. The reaction mixture was stirred at room temperature for $1 \mathrm{~h}$, diluted with $150 \mathrm{~mL}$ of hexane, and filtered. The filtrate was concentrated in vacuo to remove the excess dichlorosilane, and the resulting crude chlorosilane was dissolved in $10 \mathrm{~mL}$ of dry THF and then cooled in an ice-water bath. To another solution of $1.20 \mathrm{~g}(10.0 \mathrm{mmol})$ of 1,3-dithiane in $10 \mathrm{~mL}$ of THF cooled at $0{ }^{\circ} \mathrm{C}$ was added $7.1 \mathrm{~mL}$ (11 mmol) of n-butyllithium (1.55 $\mathrm{M}$ in hexane). The resulting solution was added slowly to the above-mentioned crude chlorosilane solution. The resulting mixture was stirred for another $30 \mathrm{~min}$ and then partitioned between $100 \mathrm{~mL}$ of ether and $60 \mathrm{~mL}$ of water. The organic layer was washed with brine $(20 \mathrm{~mL})$, dried $\left(\mathrm{MgSO}_{4}\right)$, and concentrated. The residual oil was chromatographed over silica gel (eluted with hexane/dichloromethane, 9/1, 8/2, and $7 / 3$ in sequence) to give $1.5 \mathrm{~g}(53 \%)$ of $\mathbf{8 g}$ as a colorless liquid: ${ }^{1} \mathrm{H}$ NMR $(300 \mathrm{MHz}) \delta 0.46(\mathrm{~s}, 6 \mathrm{H}), 1.90-2.16(\mathrm{~m}, 2 \mathrm{H}), 2.68$ $(\mathrm{dt}, \mathrm{J}=14.0,3.0 \mathrm{~Hz}, 2 \mathrm{H}$ ), 2.86 (ddd, J $=14.0,11.0,3.0 \mathrm{~Hz}$, $2 \mathrm{H}), 3.83(\mathrm{~s}, 3 \mathrm{H}), 4.10(\mathrm{~s}, 1 \mathrm{H}), 6.85(\mathrm{~d}, \mathrm{~J}=8.0 \mathrm{~Hz}, 1 \mathrm{H}), 6.98$ $(\mathrm{t}, \mathrm{J}=8.0 \mathrm{~Hz}, 1 \mathrm{H}), 7.39(\mathrm{t}, \mathrm{J}=8.0 \mathrm{~Hz}, 1 \mathrm{H}), 7.46(\mathrm{~d}, \mathrm{~J}=8.0$ $\mathrm{Hz}, 1 \mathrm{H}) ;{ }^{13} \mathrm{C}$ NMR $(50 \mathrm{MHz}) \delta-4.4,26.1,31.1,33.4,54.9$, $109.6,120.4,122.8,131.5,135.7,164.2$; HRMS calcd for $\mathrm{C}_{13} \mathrm{H}_{20} \mathrm{OS}_{2} \mathrm{Si} \mathrm{m} / \mathrm{z} 284.0725$, found 284.0729 .

2-[(4-Methoxyphenyl)dimethylsilyl]-1,3-dithiane (8h). According to the same procedure for the synthesis of $\mathbf{8 g}$, from $0.50 \mathrm{~g}(4.2 \mathrm{mmol})$ of 1,3-dithiane we obtained $1.0 \mathrm{~g}(85 \%)$ of 8h as a colorless liquid: ${ }^{1} \mathrm{H}$ NMR $(200 \mathrm{MHz}) \delta 0.42(\mathrm{~s}, 6 \mathrm{H})$, $1.90-2.15(\mathrm{~m}, 2 \mathrm{H}), 2.67(\mathrm{dt}, \mathrm{J}=14.0,3.0 \mathrm{~Hz}, 2 \mathrm{H}), 2.83$ (ddd, $\mathrm{J}=14.0,11.0,3.0 \mathrm{~Hz}, 2 \mathrm{H}), 3.79(\mathrm{~s}, 3 \mathrm{H}), 3.83(\mathrm{~s}, 1 \mathrm{H}), 6.92$ (br d, J $=9.0 \mathrm{~Hz}, 2 \mathrm{H}), 7.51$ (br d, J $=9.0 \mathrm{~Hz}, 2 \mathrm{H}) ;{ }^{13} \mathrm{C} \mathrm{NMR}$ $(50 \mathrm{MHz}) \delta-4.7,25.9,31.0,33.9,54.8,113.5,125.8,135.5$, 160.8; HRMS calcd for $\mathrm{C}_{13} \mathrm{H}_{20} \mathrm{OS}_{2} \mathrm{Si} \mathrm{m} / \mathrm{z} 284.0725$, found 284.0719 .

General Procedure for the Alkylation of 2-Silyl-1,3dithianes with Alkyl Dibromides followed by Hydrolysis with Red Mercuric Oxide and Boron Trifluoride Etherate. To a solution of the 2-silyl-1,3-dithiane $(3.0 \mathrm{mmol})$ in 6 $\mathrm{mL}$ of THF cooled in an ice-water bath was added dropwise over 20 min a solution of $n$-butyllithium in hexane (1.1 equiv). After another $30 \mathrm{~min}$ of stirring at $0^{\circ} \mathrm{C}$, the resulting solution 
was added over $45 \mathrm{~min}$ to a solution of the dibromide ( 2 equiv) in $5 \mathrm{~mL}$ of THF cooled at $-30^{\circ} \mathrm{C}$ using a dry ice-acetonitrile bath. The resulting mixture was stirred at the same temperature for $1.5 \mathrm{~h}$ and then partitioned between $80 \mathrm{~mL}$ of ether and $60 \mathrm{~mL}$ of water. The organic layer was washed with 50 $\mathrm{mL}$ of brine, dried $\left(\mathrm{MgSO}_{4}\right)$, and concentrated in vacuo. The residual oil was dissolved in $15 \mathrm{~mL}$ of wet THF (15\%) followed by the addition of $1.29 \mathrm{~g}(6.0 \mathrm{mmol})$ of red mercuric oxide, 1.20 $\mathrm{g}$ of Celite, and $0.73 \mathrm{~mL}(6.0 \mathrm{mmol})$ of boron trifluoride etherate. The resulting mixture was stirred at room temperature for $1 \mathrm{~h}$, diluted with ether $(80 \mathrm{~mL})$, and filtered. The filtrate was washed with brine $(30 \mathrm{~mL})$, dried $\left(\mathrm{MgSO}_{4}\right)$, and concentrated in vacuo. The residual oil was chromatographed over silica gel using hexane/ethyl acetate as eluent.

5-Bromo-1-(trimethylsilyl)pentan-1-one (10a): IR (neat) $1640 \mathrm{~cm}^{-1} ;{ }^{1} \mathrm{H}$ NMR $(200 \mathrm{MHz}) \delta 0.21(\mathrm{~s}, 9 \mathrm{H}), 1.58-1.92(\mathrm{~m}$, $4 \mathrm{H}), 2.65(\mathrm{t}, \mathrm{J}=6.0 \mathrm{~Hz}, 2 \mathrm{H}), 3.39(\mathrm{t}, \mathrm{J}=6.0 \mathrm{~Hz}, 2 \mathrm{H}) ;{ }^{13} \mathrm{C}$ NMR $(50 \mathrm{MHz}) \delta-3.4,20.5,32.1,33.2,47.0,247.1$. Anal. Calcd for $\mathrm{C}_{8} \mathrm{H}_{17} \mathrm{BrOSi}$ : C, 40.49; $\mathrm{H}, 7.22$. Found: C, 40.12; H, 7.12 .

5-Bromo-1-(triphenylsilyl)pentan-1-one (10d). To a solution of $2.0 \mathrm{~g}(5.3 \mathrm{mmol})$ of $\mathbf{8 d}$ in $10 \mathrm{~mL}$ of THF cooled in an ice-water bath was added dropwise over $10 \mathrm{~min}$ a $1.50 \mathrm{M}$ solution of $n$-butyllithium in hexane $(4.0 \mathrm{~mL}, 6.0 \mathrm{mmol})$. After another $20 \mathrm{~min}$ of stirring, the resulting mixture was added slowly over $30 \mathrm{~min}$ to a solution of $1.20 \mathrm{~mL}(10.0 \mathrm{mmol})$ of 9 in $5 \mathrm{~mL}$ of dried HMPA cooled in an ice-water bath. The reaction mixture was stirred at $0{ }^{\circ} \mathrm{C}$ for another $1 \mathrm{~h}$ and then partitioned between $150 \mathrm{~mL}$ of ether and $100 \mathrm{~mL}$ of water. The organic layer was washed with water $(100 \mathrm{~mL})$ and brine (100 mL), dried $\left(\mathrm{MgSO}_{4}\right)$, and concentrated. The residual oil was dissolved in $20 \mathrm{~mL}$ of wet THF (15\%) followed by the addition of $2.30 \mathrm{~g}(10.0 \mathrm{mmol})$ of red mercuric oxide and $2.3 \mathrm{~g}$ of Celite. The resulting mixture was cooled in an ice-water bath followed by the addition of $1.65 \mathrm{~mL}(13.3 \mathrm{mmol})$ of boron trifluoride etherate over $5 \mathrm{~min}$. The resulting mixture was stirred at room temperature for $1 \mathrm{~h}$, diluted with $40 \mathrm{~mL}$ of hexane/ethyl acetate (9/1), and filtered over a short pad of silica gel. The filtrate was concentrated, and the residual crude material was recrystallized from a mixture of $15 \mathrm{~mL}$ of hexane and $5 \mathrm{~mL}$ of ethyl acetate to give $1.69 \mathrm{~g} \mathrm{(73 \% )} \mathrm{of} \mathbf{1 0 d}$ as a white crystal: $\mathrm{mp} 133.5-134.5^{\circ} \mathrm{C}$; IR $\left(\mathrm{CH}_{2} \mathrm{Cl}_{2}\right) 1635 \mathrm{~cm}^{-1}$; ${ }^{1} \mathrm{H}$ NMR $(200 \mathrm{MHz}) \delta 1.51-1.71(\mathrm{~m}, 4 \mathrm{H}), 2.73(\mathrm{t}, \mathrm{J}=6.7 \mathrm{~Hz}, 2$ $\mathrm{H}), 3.27(\mathrm{t}, \mathrm{J}=6.5 \mathrm{~Hz}, 2 \mathrm{H}), 7.30-7.50(\mathrm{~m}, 9 \mathrm{H}), 7.51-7.63$ $(\mathrm{m}, 6 \mathrm{H}) ;{ }^{13} \mathrm{C}$ NMR $(50 \mathrm{MHz}) \delta 20.8,32.1,33.4,49.3,128.2$, 130.3, 131.1, 136.1, 242.2; HRMS calcd for $\mathrm{C}_{23} \mathrm{H}_{23} \mathrm{BrOSi} \mathrm{m} / \mathrm{z}$ 422.0702, found 422.0707 .

5-Bromo-1-(tert-butyldiphenylsilyl)pentan-1-one (10e). To a solution of $535 \mathrm{mg}(1.5 \mathrm{mmol})$ of $8 \mathbf{e}$ in $5 \mathrm{~mL}$ of THF cooled in an dry ice-acetone bath was added dropwise over $10 \mathrm{~min}$ a $1.40 \mathrm{M}$ solution of $\mathrm{n}$-butyllithium in hexane $(1.2 \mathrm{~mL}, 1.7$ $\mathrm{mmol}$ ). The resulting sol ution was stirred for another $20 \mathrm{~min}$ at the same temperature followed by the addition of $1.05 \mathrm{~mL}$ $(6.0 \mathrm{mmol})$ of HMPA and $0.20 \mathrm{~mL}(1.7 \mathrm{mmol})$ of 9 . The resulting mixture was warmed slowly to room temperature and then stirred for $1 \mathrm{~h}$. The reaction mixture was partitioned between $100 \mathrm{~mL}$ of ether and $50 \mathrm{~mL}$ of water. The organic layer was washed with water $(50 \mathrm{~mL})$ and brine $(100 \mathrm{~mL})$, dried, and concentrated. The residual oil was dissolved in 15 $\mathrm{mL}$ of wet THF (15\%) followed by the addition of $480 \mathrm{mg}(2.4$ $\mathrm{mmol}$ ) of red mercuric oxide and $480 \mathrm{mg}$ of Celite. The resulting mixture was cooled in an ice-water bath followed by the addition of $0.50 \mathrm{~mL}(4.0 \mathrm{mmol})$ of boron trifluoride etherate over $5 \mathrm{~min}$. The resulting mixture was stirred at room temperature for $1 \mathrm{~h}$, diluted with $50 \mathrm{~mL}$ of ether and filtered. The filtrate was washed with brine $(20 \mathrm{~mL})$, dried $\left(\mathrm{MgSO}_{4}\right)$, and concentrated in vacuo. The residual oil was chromatographed over silica gel (eluted with hexane/ethyl acetate, 98/2) to give $184 \mathrm{mg}(31 \%)$ of $\mathbf{1 0 e}$ as a pale yellow oil: IR (neat) $1635 \mathrm{~cm}^{-1}$; ${ }^{1} \mathrm{H}$ NMR $(300 \mathrm{MHz}) \delta 1.11$ (s, $\left.9 \mathrm{H}\right), 1.48-$ $1.58(\mathrm{~m}, 2 \mathrm{H}), 1.58-1.71(\mathrm{~m}, 2 \mathrm{H}), 2.50(\mathrm{t}, \mathrm{J}=6.7 \mathrm{~Hz}, 2 \mathrm{H})$, $3.25(\mathrm{t}, \mathrm{J}=6.7 \mathrm{~Hz}, 2 \mathrm{H}), 7.32-7.45(\mathrm{~m}, 6 \mathrm{H}), 7.57-7.66(\mathrm{~m}, 4$ $\mathrm{H}) ;{ }^{13} \mathrm{C}$ NMR $(75 \mathrm{MHz}) \delta 18.4,20.7,27.5,32.0,33.2,49.8,128.0$, 129.9, 131.7, 136.1, 244.4; HRMS calcd for $\mathrm{C}_{21} \mathrm{H}_{27} \mathrm{BrOSi} \mathrm{m} / \mathrm{z}$ 402.1015, found 402.1019 .
6-Bromo-1-[(2-methoxyphenyl)dimethylsilyl]hexan-1one (12g). To a solution of $852 \mathrm{mg}(3.0 \mathrm{mmol})$ of $\mathbf{8 g}$ in $5 \mathrm{~mL}$ of THF cooled in an ice-water bath was added dropwise over $20 \mathrm{~min}$ a $1.55 \mathrm{M}$ solution of n-butyllithium in hexane $(2.3 \mathrm{~mL}$, $3.6 \mathrm{mmol}$ ). After another $20 \mathrm{~min}$ of stirring at $0{ }^{\circ} \mathrm{C}$, the resulting solution was added over $30 \mathrm{~min}$ to a solution of 2.0 $\mathrm{mL}$ (15 mmol) of $\mathbf{1 1}$ in $10 \mathrm{~mL}$ of THF cooled at $-30{ }^{\circ} \mathrm{C}$ using a dry ice-acetonitrile bath. The resulting mixture was stirred at the same temperature for $30 \mathrm{~min}$ and then partitioned between $100 \mathrm{~mL}$ of ether and $80 \mathrm{~mL}$ of water. The organic layer was washed with $50 \mathrm{~mL}$ of brine, dried $\left(\mathrm{MgSO}_{4}\right)$, and concentrated in vacuo. The residual oil and $1.5 \mathrm{~g}(18 \mathrm{mmol})$ of sodium bicarbonate was mixed with $8 \mathrm{~mL}$ of acetonitrile and $5 \mathrm{~mL}$ of dichloromethane and then cooled in a dry iceacetonitrile bath. A mixture of $4.11 \mathrm{~g}(7.50 \mathrm{mmol})$ of CAN in $8 \mathrm{~mL}$ of acetonitrile and $1 \mathrm{~mL}$ of water was added over $1 \mathrm{~min}$ to the above mixture. The resulting mixture was stirred for $10 \mathrm{~min}$ at the same temperature and then diluted with $80 \mathrm{~mL}$ of ether and filtered. The filtrate was washed with water (80 $\mathrm{mL}$ ) and brine $(50 \mathrm{~mL})$, dried $\left(\mathrm{MgSO}_{4}\right)$, and concentrated. The residual oil was chromatographed over silica gel (eluted with hexane/ethyl acetate, $97 / 3$ ) to give $\mathbf{1 2} \mathbf{g}$ as a pale yellow oil: IR (neat) $1633 \mathrm{~cm}^{-1}{ }^{1}{ }^{1} \mathrm{H}$ NMR $(200 \mathrm{MHz}) \delta 0.42(\mathrm{~s}, 6 \mathrm{H}), 1.20-$ $1.35(\mathrm{~m}, 2 \mathrm{H}), 1.35-1.50(\mathrm{~m}, 2 \mathrm{H}), 1.76$ (quintet, J $=7.0 \mathrm{~Hz}$, $2 \mathrm{H}), 2.55(\mathrm{t}, \mathrm{J}=7.0 \mathrm{~Hz}, 2 \mathrm{H}), 3.32(\mathrm{t}, \mathrm{J}=7.0 \mathrm{~Hz}, 2 \mathrm{H}), 3.75$ $(\mathrm{s}, 3 \mathrm{H}), 6.83(\mathrm{br} d, \mathrm{~J}=8.0 \mathrm{~Hz}, 1 \mathrm{H}), 6.98$ (ddd, J = 8.0, 7.0, $1.0 \mathrm{~Hz}, 1 \mathrm{H}), 7.35-7.45(\mathrm{~m}, 2 \mathrm{H}) ;{ }^{13} \mathrm{C}$ NMR $(75 \mathrm{MHz}) \delta-4.7$, $21.2,27.8,32.5,33.6,47.5,54.9,109.5,120.9,123.2,131.8$ 135.4, 163.9, 246.1; HRMS calcd for $\mathrm{C}_{15} \mathrm{H}_{23} \mathrm{BrO}_{2} \mathrm{Si} \mathrm{m} / \mathrm{z} 342.0651$, found 342.0650 .

General Procedure for Radical Cyclizations of Bromoacylsilanes 10 and 12 . To a refluxing benzene $(10 \mathrm{~mL})$ solution of the bromoacylsilane ( $1 \mathrm{mmol}$ ) was added via syringe pump a benzene (10 $\mathrm{mL}$ ) solution of tributyltin hydride (1.2$1.5 \mathrm{mmol})$ and AIBN $(0.05 \mathrm{mmol})$ over $6 \mathrm{~h}$. The resulting solution was heated at $80^{\circ} \mathrm{C}$ for another hour and concentrated in vacuo. To the residual liquid was added a few drops of wet triethylamine, ${ }^{41}$ and the resulting mixture was chromatographed over silica gel (eluted with hexane/ethyl acetate) to isolate the products.

Cyclopentyl tert-butyldimethylsilyl ether (35b): ${ }^{1} \mathrm{H}$ NMR $(200 \mathrm{MHz}) \delta 0.02(\mathrm{~s}, 6 \mathrm{H}), 0.86(\mathrm{~s}, 9 \mathrm{H}), 1.40-1.55(\mathrm{~m}, 4$ $\mathrm{H}), 1.60-1.75(\mathrm{~m}, 4 \mathrm{H}), 4.21$ (quintet, J $=5 \mathrm{~Hz}, 1 \mathrm{H}) ;{ }^{13} \mathrm{C}$ NMR $(50 \mathrm{MHz}) \delta-4.7,18.2,23.1,25.9,35.7,74.4$; HRMS calcd for $\mathrm{C}_{11} \mathrm{H}_{24} \mathrm{OSi} \mathrm{m} / \mathrm{z} 200.11596$, found 200.1601 .

Radical Cyclization of 14. cis- and trans-2-Methylcyclopentyl Methyldiphenylsilyl Ether (cis- and trans-38). To a refluxing solution of $150 \mathrm{mg}(0.400 \mathrm{mmol})$ of 14 in 0.4 $\mathrm{mL}$ of benzene was added via syringe pump over $30 \mathrm{~min}$ a solution of $0.129 \mathrm{~mL}(0.48 \mathrm{mmol})$ of tributyltin hydride and $3.5 \mathrm{mg}(0.022 \mathrm{mmol})$ of AIBN in $0.4 \mathrm{~mL}$ of benzene. The resulting solution was stirred for $2 \mathrm{~h}$ at $80{ }^{\circ} \mathrm{C}$ and then concentrated in vacuo. To the residual liquid was added a few drops of wet triethylamine, ${ }^{41}$ and the resulting mixture was chromatographed over silica gel (eluted with hexane) to give $50 \mathrm{mg}(42 \%)$ of cis-38 as a colorless liquid: ${ }^{1} \mathrm{H}$ NMR $(200 \mathrm{MHz})$ $\delta 0.65(\mathrm{~s}, 3 \mathrm{H}), 1.01(\mathrm{~d}, \mathrm{~J}=6.5 \mathrm{~Hz}, 3 \mathrm{H}), 1.30-1.94(\mathrm{~m}, 7 \mathrm{H})$, $4.16(\mathrm{q}, \mathrm{J}=4.0 \mathrm{~Hz}, 1 \mathrm{H}), 7.26-7.46(\mathrm{~m}, 6 \mathrm{H}), 7.48-7.70(\mathrm{~m}, 4$ $\mathrm{H}) ;{ }^{13} \mathrm{C}$ NMR $(50 \mathrm{MHz}) \delta-2.4,14.5,21.8,30.8,34.7,39.8$, 127.7, 129.5, 134.4, 137.1. Anal. Calcd for $\mathrm{C}_{19} \mathrm{H}_{24} \mathrm{OSi}$ : C, 76.97; $\mathrm{H}, 8.16$. Found: $\mathrm{C}, 76.48 ; \mathrm{H}, 8.12$. Further elution gave $45 \mathrm{mg}$ (38\%) of trans-38 as a colorless liquid: ${ }^{1} \mathrm{H}$ NMR (200 $\mathrm{MHz}) \delta 0.66(\mathrm{~s}, 3 \mathrm{H}), 0.89(\mathrm{~d}, \mathrm{~J}=6.0 \mathrm{~Hz}, 3 \mathrm{H}), 0.99-1.21(\mathrm{~m}$, $1 \mathrm{H}), 1.51-2.03(\mathrm{~m}, 6 \mathrm{H}), 3.77(\mathrm{q}, \mathrm{J}=6.0 \mathrm{~Hz}, 1 \mathrm{H}), 7.26-7.43$ $(\mathrm{m}, 6 \mathrm{H}), 7.50-7.68(\mathrm{~m}, 4 \mathrm{H}) ;{ }^{13} \mathrm{C}$ NMR $(50 \mathrm{MHz}) \delta-2.3,18.1$, $21.4,31.2,34.2,42.5,81.3,127.7,129.6,134.3,136.9$; HRMS calcd for $\mathrm{C}_{19} \mathrm{H}_{24} \mathrm{OSi} \mathrm{m} / \mathrm{z} 296.1597$, found 296.1597.

Radical Cyclization of 16. 1-(Methyldiphenylsilyl)heptan-1-one (39), cis- and trans-2-Methylcyclohexyl Methyldiphenylsilyl Ether (cis- and trans-40). To a refluxing solution of $100 \mathrm{mg}(0.257 \mathrm{mmol})$ of $16 \mathrm{in} 22 \mathrm{~mL}$ of benzene was added via syringe pump over $2 \mathrm{~h}$ a solution of $0.090 \mathrm{~mL}(0.33 \mathrm{mmol})$ of tributyltin hydride and $3.0 \mathrm{mg}(0.019$

(41) Curran, D. P.; Chang, C.-T. J . Org. Chem. 1989, 54, 3140. 
mmol) of AIBN in $7.1 \mathrm{~mL}$ of benzene. The resulting solution was stirred for $2 \mathrm{~h}$ at $80^{\circ} \mathrm{C}$ and then concentrated in vacuo. To the residual liquid was added a few drops of wet triethylamine, ${ }^{41}$ and the resulting mixture was chromatographed over silica gel (eluted with hexane followed by hexane/ethyl acetate, 99/1) to give $13 \mathrm{mg}(\mathbf{1 7 \%})$ of cis-40 as a colorless liquid: ${ }^{1 \mathrm{H}}$ NMR $(200 \mathrm{MHz}) \delta 0.63(\mathrm{~s}, 3 \mathrm{H}), 0.87(\mathrm{~d}, \mathrm{~J}=6.0 \mathrm{~Hz}, 3 \mathrm{H})$, $1.08-1.82(\mathrm{~m}, 9 \mathrm{H}), 3.75-3.90(\mathrm{~m}, 1 \mathrm{H}), 7.26-7.46(\mathrm{~m}, 6 \mathrm{H})$, 7.50-7.70 (m, $4 \mathrm{H}) ;{ }^{13} \mathrm{C}$ NMR $(50 \mathrm{MHz}) \delta-2.3,17.6,20.9,24.7$, 29.1, 33.0, 36.7, 72.5, 127.7, 129.5, 134.4, 137.2. Anal. Calcd for $\mathrm{C}_{20} \mathrm{H}_{26} \mathrm{OSi}$ : C, 77.37; $\mathrm{H}, 8.44$. Found: $\mathrm{C}, 77.37 ; \mathrm{H}, 8.19$. Further elution gave $32 \mathrm{mg}$ (40\%) of trans-40 as a colorless liquid: ${ }^{1} \mathrm{H}$ NMR $(200 \mathrm{MHz}) \delta 0.65(\mathrm{~s}, 3 \mathrm{H}), 0.93(\mathrm{~d}, \mathrm{~J}=6.5$ $\mathrm{Hz}, 3 \mathrm{H}), 1.00-1.87(\mathrm{~m}, 9 \mathrm{H}), 3.24(\mathrm{td}, \mathrm{J}=10.0,4.0 \mathrm{~Hz}, 1 \mathrm{H})$, $7.28-7.45(\mathrm{~m}, 6 \mathrm{H}), 7.52-7.68(\mathrm{~m}, 4 \mathrm{H}) ;{ }^{13} \mathrm{C}$ NMR $(50 \mathrm{MHz}) \delta$ $-2.1,19.3,25.1,25.6,33.6,35.8,40.2,78.0,127.7,129.6,134.4$, 137.1. Anal. Calcd for $\mathrm{C}_{20} \mathrm{H}_{26} \mathrm{OSi}$ : C, 77.37; $\mathrm{H}, 8.44$. Found: C, 77.17; H, 8.19. Continued elution gave $31 \mathrm{mg} \mathrm{(39 \% )} \mathrm{of} 39$ as a pale yellow liquid: IR (neat) $1679,1427,1112 \mathrm{~cm}^{-1} ;{ }^{1} \mathrm{H}$ NMR $(200 \mathrm{MHz}) \delta 0.75(\mathrm{~s}, 3 \mathrm{H}), 0.82(\mathrm{t}, \mathrm{J}=7.0 \mathrm{~Hz}, 3 \mathrm{H}), 1.05-$ $1.34(\mathrm{~m}, 6 \mathrm{H}), 1.45$ (quintet, J $=7.0 \mathrm{~Hz}, 2 \mathrm{H}), 2.62(\mathrm{t}, \mathrm{J}=7.0$ $\mathrm{Hz}, 2 \mathrm{H}), 7.30-7.49(\mathrm{~m}, 6 \mathrm{H}), 7.49-7.66(\mathrm{~m}, 4 \mathrm{H}) ;{ }^{13} \mathrm{C} N M R$ $(50 \mathrm{MHz}) \delta-5.3,14.0,22.1,22.4,28.8,31.6,49.7,128.1,130.0$, 132.8, 134.9, 244.7. Anal. Calcd for $\mathrm{C}_{20} \mathrm{H}_{26} \mathrm{OSi}$ : C, 77.36; $\mathrm{H}$, 8.44. Found: C, 76.98; H, 8.37.

General Procedure for Radical Cyclizations of 12a-C using $E t_{3} B$ and Air for Initiation. To a solution of the bromide $(1 \mathrm{mmol})$ and triethylborane $(1.3 \mathrm{mmol} ; 1 \mathrm{M}$ in hexane) in $5 \mathrm{~mL}$ of benzene was added via syringe pump over $2 \mathrm{~h}$ a solution of tributyltin hydride (1.3 equiv). During the same period, a slow stream of dry air was passed through the solution via syringe pump. The resulting solution was stirred at room temperature for another hour. The reaction mixture was then analyzed with gas chromatography using a $3.3 \mathrm{~mm}$ $\times 3$ m column ( $10 \%$ SE 30 on chromosorb W, 80-100 mesh) with a flow rate of $30 \mathrm{~mL} / \mathrm{min}: \mathrm{t}_{\mathrm{R}}(\mathbf{3 6 a})=4.42 \mathrm{~min}\left(130^{\circ} \mathrm{C}\right)$; $t_{R}(37 a)=6.19 \min \left(130^{\circ} \mathrm{C}\right) ; t_{R}(36 b)=6.90 \min \left(170{ }^{\circ} \mathrm{C}\right) ; t_{R}$ $(\mathbf{3 7 b})=9.26 \mathrm{~min}\left(170^{\circ} \mathrm{C}\right) ; t_{R}(36 \mathbf{c})=13.84 \mathrm{~min}\left(230^{\circ} \mathrm{C}\right) ; t_{R}$ $(37 \mathrm{c})=18.27 \mathrm{~min}\left(230^{\circ} \mathrm{C}\right)$.

Radical Cyclization of 24. Methyldiphenylsilyl 1-Indanyl Ether (49). To a refluxing benzene $(1.5 \mathrm{~mL})$ solution of $124 \mathrm{mg}(0.302 \mathrm{mmol})$ of $\mathbf{2 4}$ was added via syringe pump a benzene $(1.5 \mathrm{~mL})$ solution of $0.094 \mathrm{~mL}(0.36 \mathrm{mmol})$ of tributyltin hydride and $2.5 \mathrm{mg}(0.015 \mathrm{mmol})$ of AIBN over $2 \mathrm{~h}$. The resulting solution was heated at $80{ }^{\circ} \mathrm{C}$ for another $2 \mathrm{~h}$ and concentrated in vacuo. To the residual liquid was added a few drops of wet triethylamine, ${ }^{41}$ and the resulting mixture was chromatographed over silica gel (eluted with hexane/ethyl acetate, 98/2) to give $82 \mathrm{mg}(83 \%)$ of $\mathbf{4 9}$ as a colorless liquid: ${ }^{1} \mathrm{H}$ NMR (300 MHz) $\delta 0.79(\mathrm{~s}, 3 \mathrm{H}), 2.09$ (dtd, J = 12.7, 8.0, $6.6 \mathrm{~Hz}$, when irradiated at $\delta 5.42$ collapsed into a dt, $\mathrm{J}=12.7$, $8.0 \mathrm{~Hz}, 1 \mathrm{H}), 2.30-2.41(\mathrm{~m}$, when irradiated at $\delta 5.42$ collapsed into a ddd, $\mathrm{J}=12.7,8.0,3.7 \mathrm{~Hz}, 1 \mathrm{H}), 2.76(\mathrm{dt}, \mathrm{J}=15.8,8.0$ $\mathrm{Hz}, 1 \mathrm{H}), 3.04$ (ddd, J = 15.8, 8.0, 3.7 Hz, $1 \mathrm{H}), 5.42(\mathrm{t}, \mathrm{J}=6.6$ $\mathrm{Hz}, 1 \mathrm{H}), 7.15-7.25(\mathrm{~m}, 1 \mathrm{H}), 7.26-7.35(\mathrm{~m}, 1 \mathrm{H}), 7.36-7.51$ $(\mathrm{m}, 8 \mathrm{H}), 7.70-7.75(\mathrm{~m}, 4 \mathrm{H}) ;{ }^{13} \mathrm{C} \mathrm{NMR}(75 \mathrm{MHz}) \delta-2.2,29.7$, $36.2,77.0,124.4,124.6,126.3,127.7,127.8,129.7,134.4,136.4$, 142.7, 145.0. Anal. Calcd for $\mathrm{C}_{22} \mathrm{H}_{22} \mathrm{OSi}$ : C, 79.95; $\mathrm{H}, 6.71$. Found: C, 79.84; H, 6.72.

Radical Cyclization of 28. 1-Cyclopenten-1-yl Methyldiphenylsilyl Ether (60). To a refluxing benzene $(10 \mathrm{~mL})$ solution of $360 \mathrm{mg}(1.0 \mathrm{mmol})$ of $\mathbf{2 8}$ was added via syringe pump a benzene $(10 \mathrm{~mL})$ solution of $0.35 \mathrm{~mL}(1.3 \mathrm{mmol})$ of tributyltin hydride and $25 \mathrm{mg}(0.15 \mathrm{mmol})$ of AIBN over $2 \mathrm{~h}$. The resulting solution was heated at $80^{\circ} \mathrm{C}$ for another $1 \mathrm{~h}$. Throughout the reaction period, the reaction mixture was irradiated with two $100 \mathrm{~W}$ tungsten lamps. The resulting solution was concentrated in vacuo. Tothe residual liquid was added a few drops of wet triethylamine, ${ }^{41}$ and the resulting mixture was chromatographed over silica gel (eluted with hexane/ethyl acetate, 99/1) to give $173 \mathrm{mg}(62 \%)$ of 60 as a colorless liquid: IR (neat) $1637 \mathrm{~cm}^{-1} ;{ }^{1} \mathrm{H}$ NMR $(300 \mathrm{MHz}) \delta$ $0.72(\mathrm{~s}, 3 \mathrm{H}), 1.80$ (quintet, J $=7.2 \mathrm{~Hz}, 2 \mathrm{H}), 2.13-2.31(\mathrm{~m}, 4$ $\mathrm{H}), 4.57(\mathrm{t}, \mathrm{J}=2.0 \mathrm{~Hz}, 1 \mathrm{H}), 7.29-7.44(\mathrm{~m}, 6 \mathrm{H}), 7.54-7.68$ $(\mathrm{m}, 4 \mathrm{H}) ;{ }^{13} \mathrm{C}$ NMR $(75 \mathrm{MHz}) \delta-2.7,21.2,28.6,33.4,103.4$, $127.8,129.9,134.3,135.7,154.7$; HRMS calcd for $\mathrm{C}_{18} \mathrm{H}_{20} \mathrm{OSi}$ $\mathrm{m} / \mathrm{z} 280.1284$, found 280.1295 .

Acknowledgment. Financial support by the National Science Council of the Republic of China is gratefully acknowledged.

Supporting Information Available: Details of compound characterization of $\mathbf{1 0 b}, \mathbf{c}, \mathbf{1 2 a}, \mathbf{b}, \mathbf{f}, \mathbf{1 4}, \mathbf{1 6}, \mathbf{1 2 d}, \mathbf{e , h}, \mathbf{2 6}, \mathbf{2 8}, \mathbf{3 0}$ $32,34,35 c-e, 36 c-h, 37 c-g, 50,61,62,64$, and $65 ;{ }^{1} \mathrm{H}$ and ${ }^{13} \mathrm{C}$ NMR spectra of new compounds lacking analysis (34 pages). This material is contained in libraries on microfiche, immediately follows this article in the microfilm version of the journal, and can be ordered from the ACS; see any current masthead page for ordering information.

J 09711302 